\title{
Green Chemical Treatments for Heating and Cooling Systems
}




\section{Green Chemical Treatments for Heating and Cooling Systems}

Susan A. Drozdz and Vincent F. Hock

Construction Engineering Research Laboratory (CERL)

U.S. Army Engineer Research and Development Center

2902 Newmark Dr.

Champaign, IL 61824

Final Report

Prepared for U.S. Army Corps of Engineers

Washington, DC 20314-1000 


\begin{abstract}
The development of current selection and application guidance is necessary to help Army installations be "smart buyers" of water treatment for new and existing heating and cooling systems. Manufacturers continue to introduce new chemicals and treatment programs onto the market, including environmentally friendly "green" chemical products, as old products are discontinued. These products require periodic review to inform Army installations of new technological advances, and of the capabilities of chemical products available in the marketplace.
\end{abstract}

This work demonstrated and evaluated the performance of primary water treatment formulations at Fort Stewart, GA and Fort Hood, TX, using three "green" chemical technologies: (1) the cooling water inhibitor polyaspartate (PASP), (2) the cooling water biocide tetrakis (hydroxymethyl) phosphonium sulfate (THPS), and (3) a filming inhibitor made from exthoxalated soya amines (for steam line treatment). The study concluded that the three technologies were effective when used according to the recommended application guidelines.

DISCLAIMER: The contents of this report arenot to beused for advertising, publication, or promotional purposes. Citation of trade names does not constitute an official endorsement or approval of the use of such commercial products. All product names and trademarks cited are the property of their respective owners. The findings of this report are not to beconstrued as an official Department of the Army position unless so designated by other authorized documents. 


\section{Contents}

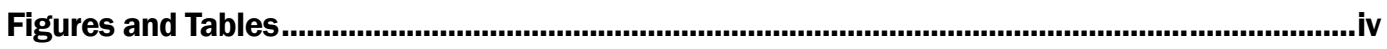

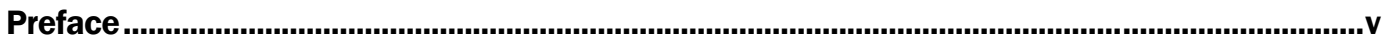

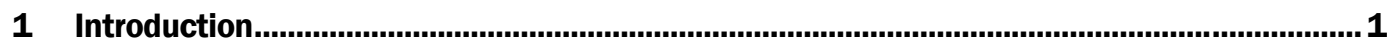

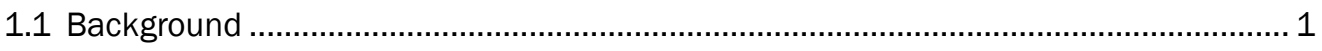

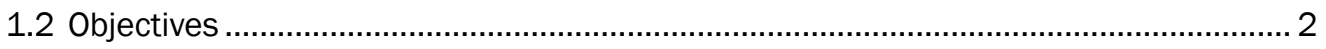

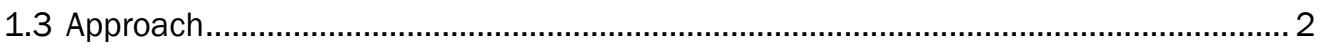

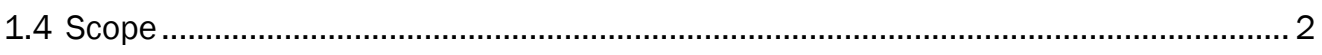

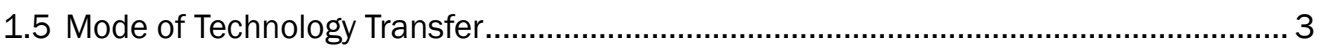

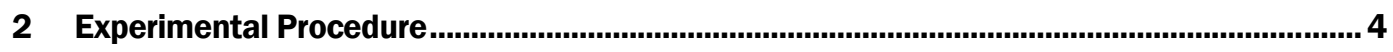

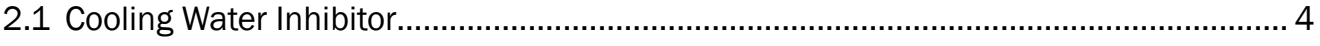

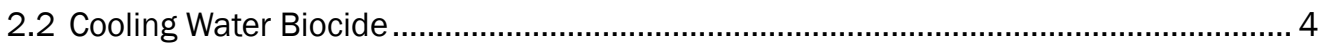

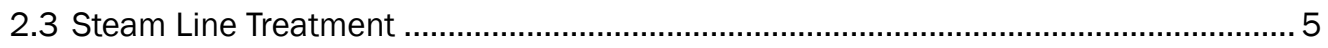

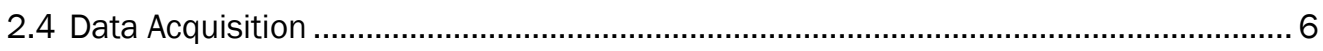

$\begin{array}{lll}\text { 2.4.1 Fort Hood Supply Water } & 7\end{array}$

2.4.2 Fort Stewart Supply Water 8

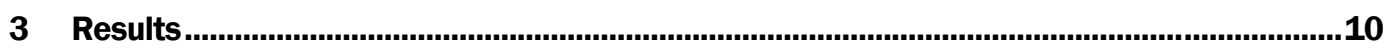

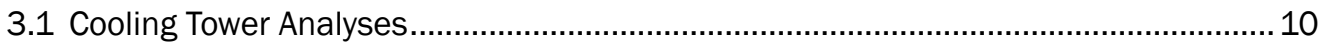

$\begin{array}{lll}\text { 3.1.1 Scale Control } & 11\end{array}$

3.1.2 Cycles of Concentration 13

$\begin{array}{lll}\text { 3.1.3 Bio Control } & 15\end{array}$

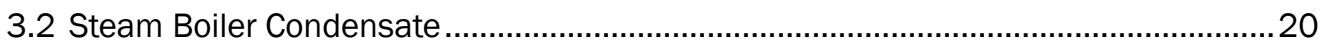

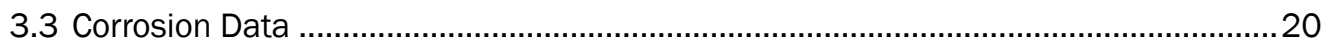

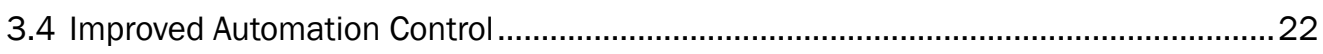

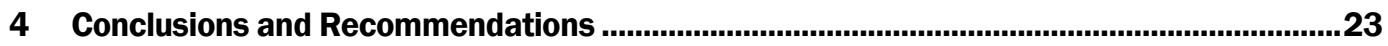

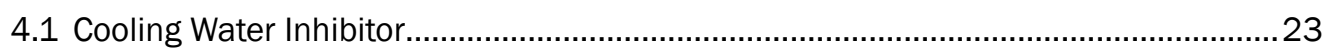

$\begin{array}{lll}4.1 .1 & \text { Conclusions } & 23\end{array}$

$\begin{array}{lll}\text { 4.1.2 Recommendations } & 23\end{array}$

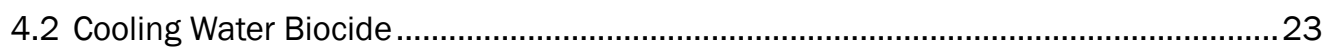

4.2.1 Conclusions 23

4.2.2 Recommendation $\quad 24$

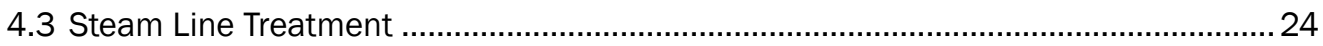

$\begin{array}{lll}4.3 .1 & \text { Conclusions } & 24\end{array}$

$\begin{array}{lll}\text { 4.3.2 Recommendation } & 24\end{array}$

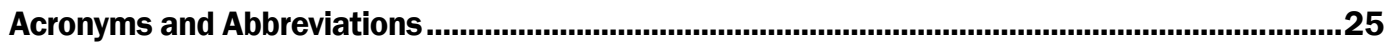

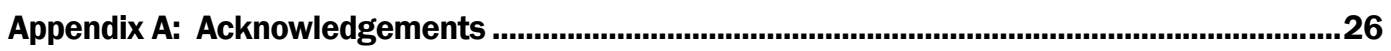

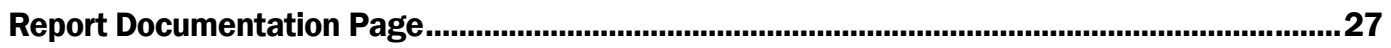




\section{Figures and Tables}

\section{Figures}

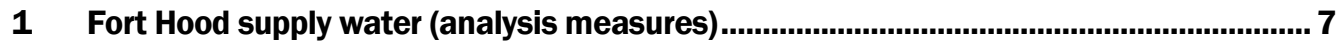

2 Fort Hood supply water (analysis min/max/avg.)........................................................ 7

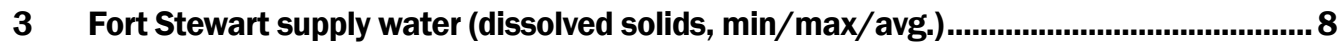

4 Fort Stewart supply water (avg. dissolved solids, all towers) ….................................... 9

5 Laboratory results for the Fort Hood cooling towers .................................................10

6 Field analysis for the Fort Stewart cooling towers .......................................................10

7 Molybdate analysis of the Fort Hood cooling tower ......................................................11

8 Average molybdenum for all towers at Fort Stewart ..................................................11

9 Cooling tower conductivity at Fort Hood.................................................................12

10 Average conductivity of all cooling towers at Fort Stewart..........................................12

11 Cycles of concentration at Fort Hood.............................................................................13

12 Cycles of concentration for all towers at Fort Stewart..................................................14

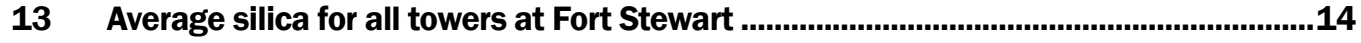

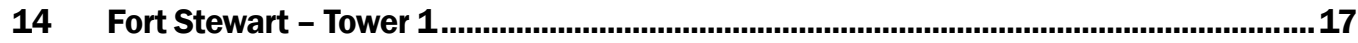

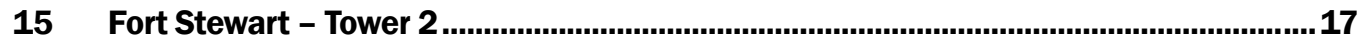

16 Fort Stewart - Tower 3

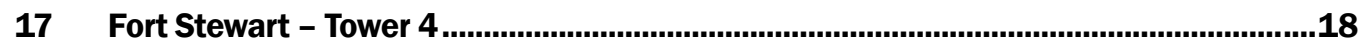

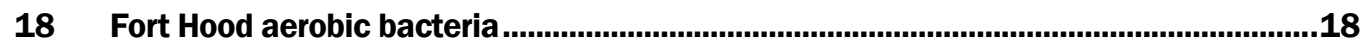

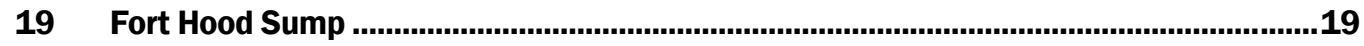

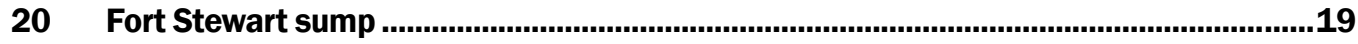

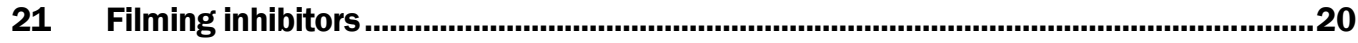

22 Corrator results and analyses for cooling towers and condensate at Fort Hood..........21

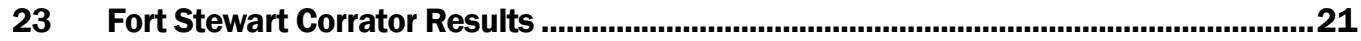

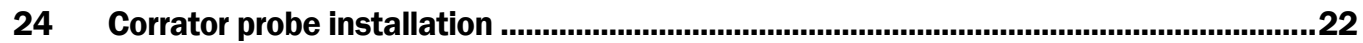

\section{Tables}

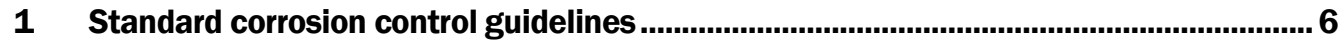

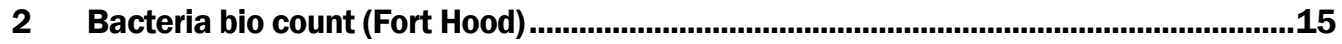

3 Aerobic bacteria bio count (Fort Stewart),.....................................................................16 


\section{Preface}

This study was conducted for the U.S. Army Forces Command (FORSCOM) under reimbursable Project "Performance Demonstration of Corrosion Control and Prevention." The technical monitors were William Timmerman and Daniel Copeland, Fort McPherson, GA.

The work was performed by the Materials and Structures Branch (CF-M) of the Facilities Division (CF), Construction Engineering Research Laboratory (CERL). The CERL Principal Investigators were Vincent F. Hock and Susan A. Drozdz. Additional technical review was provided by Paul Volkman, Installation Management Agency (IMA), Martin Savoie is Chief, CEERD-CF-M, and Michael Golish is Chief, CEERD-CF. The Director of CERL is Dr. Ilker R. Adiguzel.

CERL is an element of the U.S. Army Engineer Research and Development Center (ERDC), U.S. Army Corps of Engineers. The Commander and Executive Director of ERDC is COLJ ames R. Rowan and the Director of ERDC is Dr. J ames R. Houston. 


\section{Introduction}

\subsection{Background}

The development of up-to-date selection and guidance is necessary to help Army installations be "smart buyers" of water treatment chemicals for new and existing heating and cooling systems. The lack of current and consistent guidelines has resulted in poor control of water treatment at many facilities. Poor control has resulted in reduced system reliability and efficiency, and also in increased maintenance costs due to premature failure of systems and components. Specifically, treatment for cooling towers, steam boilers, condensate return systems, and closed heating and cooling systems (including central plant heating and cooling systems, and building HVAC systems) needs to be addressed.

Manufacturers continue to introduce new chemicals and treatment programs onto the market, and old products have been discontinued. A significant number of new chemical water-treatment formulations have been introduced in the past several years, most notably in the areas of:

(1) phosphonates and phosphonate alternatives and new, highly effective polymers for scale inhibition, (2) microbiocides for inhibition of bacteria and algae, and (3) new formulations for corrosion inhibition. Furthermore, there has been an increased interest and emphasis on environmentally friendly ("green") chemicals. The term "environmentally friendly" refers to the environmental persistence of the chemical, and to the environmental impact of the production of the compound and eventual disposal of the spent chemical mixture.

The U.S. Army Corps of Engineers (USACE) and Army have not evaluated these new chemicals in over 10 years. Therefore, Army installations may be uninformed as to new treatment technologies. This work was undertaken to test the performance of primary water treatment formulations at Fort Stewart, GA and Fort Hood, TX, using three "green" chemical technologies:

1. The cooling water inhibitor polyaspartate (PASP)

2. The cooling water biocide tetrakis (hydroxymethyl) phosphonium sulfate (THPS)

3. A filming inhibitor made from exthoxalated soya amines (for steam line treatment). 


\subsection{Objectives}

The objectives of this work were to test and evaluate current state-of-theart treatment schemes using environmentally friendly "green" technologies, to confirm the effectiveness of selected treatment programs in field installations, and to make recommendations that may contribute to the development of updated guidelines for chemical treatment programs using those technologies in heating and cooling systems.

\subsection{Approach}

1. Operating system data for the studied systems were acquired and analyzed, including field service tests and monthly water samples.

2. Cooling Water Inhibitor Formula G-C 2610 was used at Fort Hood and Fort Stewart at a prescribed total inhibitor treatment dosage level of 100-150 ppm. Secondary additives were used for mild steel corrosion and scale protection. A small amount of molybdenum was added to track dosage levels. Two sets of corrosion coupons were exposed and analyzed to support the in-plant corrator corrosion readings in both the cooling systems and the boiler condensate. Corrator probes were copper and mild steel in cooling waters and mild steel only in the boiler condensate. The Garratt-Callahan Lab tested for metals to supplement the results of the corrosion coupons.

3. A cooling water biocide (Garratt-Callahan formula 3004) was fed two times per week for bio control. Microbial monitoring for algae was done visually (using pictures), and for bacteria using Sani-Check bacteria and fungi $(\mathrm{BF})$ dip slides.

4. A biodegradable filming inhibitor, Garratt-Callahan 4055, was applied to the steam line for corrosion control. Two sets of corrosion coupons were exposed and analyzed to support the in-plant corrator corrosion readings in both the cooling systems and the boiler condensate. Laboratory tests were done for metals to supplement the results of the corrosion coupons.

5. Results were recorded and analyzed, conclusions were drawn, and recommendations formulated to supplement updated guidelines for chemical treatment programs using those technologies in heating and cooling systems.

\subsection{Scope}

Field measurements during this project were taken during normal daily operations at Fort Stewart and Fort Hood, and were done to minimize 
possible inconvenience to installation personnel. For example, Fort Hood and Fort Stewart requested that the equipment not be reopened for the project, as preventative maintenance had already been performed, and minimal disruption was a major consideration with the project. While such necessary accommodation may have limited the ability to visually inspect the results of the subject chemical treatments, it did not compromise the integrity of the instrumental measurements that form the basis for the study's resulting conclusions and recommendations.

\subsection{Mode of Technology Transfer}

This report will be made accessible through the World Wide Web (WWW) through URL:

http://www.cecer.army.mil 


\section{Experimental Procedure}

Engineer Research and Development Center, Construction Engineering Research Laboratory (ERDC-CERL) and the Garratt-Callahan Company developed chemical formulations based on products considered to be more environmentally friendly than the cooling and boiler products routinely used in industry today. This study tested three primary water treatment formulations using Green Chemical Technologies.

\subsection{Cooling Water Inhibitor}

ERDC-CERL and Garratt-Callahan formulated a method of condenser water treatment with a key ingredient being polyaspartate (PASP). Polyaspartic acid was the 1996 Presidential Green Chemistry Challenge Award Winner, and has proven to be an excellent dispersant and crystal modifier. This product is a water-soluble, biodegradable dispersant that is very environmentally friendly and functions well in condenser water treatment formulations. Garratt-Callahan developed two formulations with this ingredient (formula G-C 2600 and formula GC 2610).

Formula G-C 2600 was developed for supply waters with moderate hardness and alkalinity. Formula G-C 2610 was developed for waters with high hardness and high alkalinity. Formula G-C 2610 was used at Fort Hood and Fort Stewart, at a prescribed total inhibitor treatment dosage level of 100-150 ppm. Secondary additives included benzotriazole (BZT) for copper corrosion protection and two phosphonates, 2-Phosphonobutane1,2,4-Tricarboxylic Acid (PBTC), and 1-Hydroxyethane-(1,1-di-phosphonic acid) (HEDP), for mild steel corrosion and scale protection. A small amount of molybdenum was added to track dosage levels.

\subsection{Cooling Water Biocide}

The second product evaluated was the cooling water biocide tetrakis (hydroxymethyl) phosphonium sulfate (THPS). THPS won the Presidential Green Chemistry Challenge Award in 1997. The recommended treatment level is below that which would be toxic to fish. In addition, THPS rapidly breaks down in the environment through hydrolysis, oxidation, photodegradation, and biodegradation. Also, because THPS is halogen-free, and 
does not contain volatile organic compounds, it does not contribute to dioxin or adsorbable organically bound halogens (AOX) formation.

This single product is Garratt-Callahan formula 3004, which was fed two times per week for bio control. Garratt-Callahan formula 3004 is classified as a broad spectrum, non-foaming microbiocide that is not affected by hard water when used at recommended levels. It may be used to control aerobic and anaerobic bacteria, especially the sulfate reducing bacteria. It is compatible with corrosion and scale inhibitors and with other nonoxidizing biocides. However, it is not compatible with oxidizing biocides and should not be applied in closed loops where sulfites and bisulfites are used as oxygen scavengers.

Note that, normally, two biocides are applied to cooling systems since it is rare for any one material to provide equal performance against both algae and bacteria. The overall synergistic effect is reduced when only one material is applied. Generally, biocides are rated in their effectiveness against all organism classifications; that same analysis is used here.

Microbial monitoring for algae was done visually (using pictures), and for bacteria using Sani-Check BF dip slides. "Good control" of aerobic bacteria was considered to be 500,000 organisms/ $\mathrm{ml}$ or less and "excellent control" was considered to be 100,000 organisms/ $\mathrm{ml}$ or less. The only acceptable count for anaerobic bacteria is zero organisms $/ \mathrm{ml}$, which was tested with the use of the Sani-Check anaerobic test kit, commonly used in industry. The cooling towers were also physically inspected during the evaluation process.

The product was found to be particularly effective against bacteria. It will be important to supplement this effective bactericide with a non-oxidizing material that has been proven to be very effective in preventing algae growth. Obtaining a representative water sample in a cooling tower is no easy task. However, the fact that the bacteria counts were very low raised the question of whether the product would also be effective against the potentially deadly Legionella pneumophila bacterium, which causes Legionnaire's Disease.

\subsection{Steam Line Treatment}

The third and final product in the Green Chemistry project was a filming inhibitor made from exthoxalated soya amines. The specification for this product was the basis for Garratt-Callahan formula 4005, and was applied 
both at Fort Hood and at Fort Stewart. This product is used to control both oxygen and carbon dioxide corrosion in steam lines by forming a monomolecular protective film barrier on metal surfaces.

Although more toxic than the two Presidential Award Winners, this material is inherently biodegradable; a closed bottle test showed a 42 percent biodegradability at day 28 and a 54 percent biodegradability at day 42 . The normal dosage is 2 to $3 \mathrm{lb}$ of active ingredient per 100,000 lb of steam generated. (Overfeed of the material may cause foaming.) The product is applied directly to the steam header. The initial startup dosage must be minimal to reduce loose iron put in solution as the film-forming process cleans the condensate line during film development.

The additional oxygen protection provided by a film forming material (as compared to conventional neutralizing amines) is a very important characteristic of this product since it can still be effective when steam boilers are put on stand-by, with the resulting significant decrease in steam line temperature and pressure. Overall corrosion data was good, although there were spikes when the dosage was not maintained and when the condensate line was not full (at which time the corrator tip was not totally submerged in condensate).

\subsection{Data Acquisition}

For any research project to develop accurate conclusions, a significant amount of actual operating system data is required. The sources of this data include field service tests and monthly water samples. Two sets of corrosion coupons were exposed and analyzed to support the in-plant corrator corrosion readings in both the cooling systems and the boiler condensate. Corrator probes were copper and mild steel in cooling waters and mild steel only in the boiler condensate. The Garratt-Callahan Lab tested for metals to supplement the results of the corrosion coupons. Table 1 lists the corrosion standards that were used.

Table 1. Standard corrosion control guidelines.

\begin{tabular}{|l|c|c|c|}
\hline Coupon Metal & Good Control & Excellent Control & Out of Control \\
\hline Mild Steel & $<5 \mathrm{mpy}$ & $<2 \mathrm{mpy}$ & $>6 \mathrm{mpy}$ \\
\hline Copper & $<0.2 \mathrm{mpy}$ & $<0.1 \mathrm{mpy}$ & $>0.3 \mathrm{mpy}$ \\
\hline $304 \mathrm{SS}$ & $<1 \mathrm{mpy}$ & $<0.5 \mathrm{mpy}$ & $>2 \mathrm{mpy}$ \\
\hline Aluminum & $<0.8 \mathrm{mpy}$ & $<0.4 \mathrm{mpy}$ & $>1.5 \mathrm{mpy}$ \\
\hline Galvanized & $<3 \mathrm{mpy}$ & $<1.5 \mathrm{mpy}$ & $>4 \mathrm{mpy}$ \\
\hline
\end{tabular}




\subsubsection{Fort Hood Supply Water}

The supply water at Fort Hood is consistently a moderately hard water supply that is low in silica. Figures 1 and 2 show the laboratory supply water analyses and resulting measures of Calcium Hardness, Total Alkalinity (LSI/RSI), ${ }^{*}$ and $\mathrm{pH}$ levels.

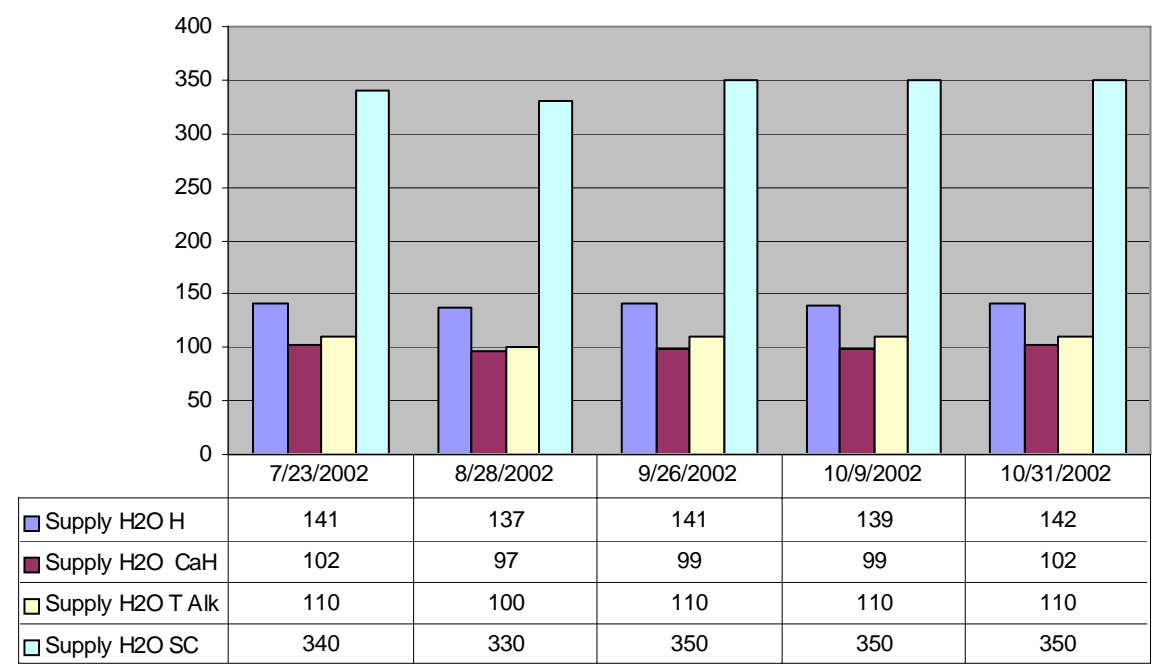

Figure 1. Fort Hood supply water (analysis measures).

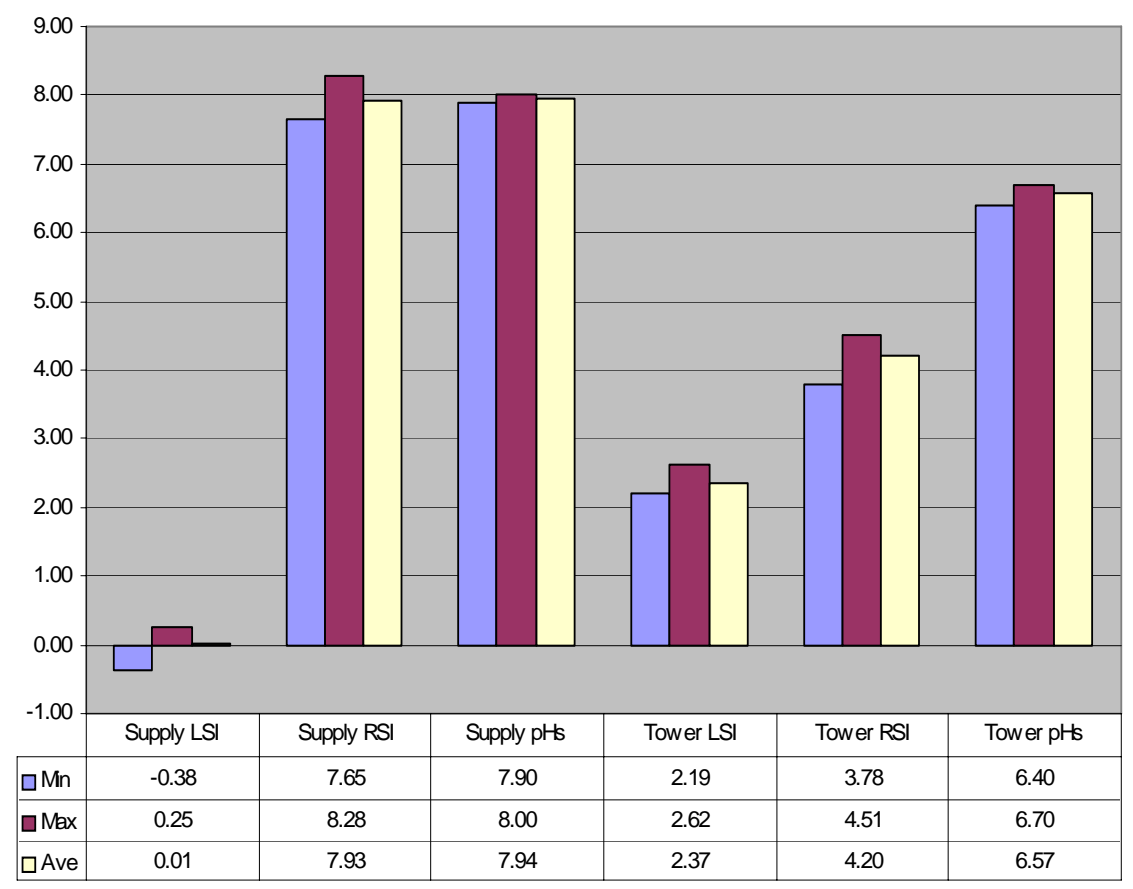

Figure 2. Fort Hood supply water (analysis min/max/avg.).

\footnotetext{
* Langlier's Saturation Index (LSI); Ryznar's Stability Index (RSI).
} 


\subsubsection{Fort Stewart Supply Water}

The Fort Stewart water supply is subject to a wide range of dissolved solid concentrations, reflected in all key operating parameters (Figures 3 and 4). Note the silica change from $21 \mathrm{ppm}$ to $48 \mathrm{ppm}$. Silica was a key component in previous deposit analyses. The calcium hardness swing was from a low of $40 \mathrm{ppm}$ to a high of $140 \mathrm{ppm}$, with the total hardness varying from a low of $64 \mathrm{ppm}$ to a high of $290 \mathrm{ppm}$. Typically, the magnesium ion reacts with the silica to form magnesium silicate. The magnesium hardness may be determined by subtracting the calcium hardness from the total hardness.

It is difficult to use the chloride ion as a hardness balance when the supply water chloride varies from a minimum of $8 \mathrm{ppm}$ to a high of $26 \mathrm{ppm}$. Even the total alkalinity had a swing from $78 \mathrm{ppm}$ to $190 \mathrm{ppm}$.

At this location, each test series had to be closely reviewed and analyzed for the tendency to precipitate either calcium carbonate (scale) or magnesium silicate deposits. If necessary, the total conductivity control range must be lowered to prevent exceeding solubility levels and the reaction of calcium, magnesium, silica, and alkalinity ions.

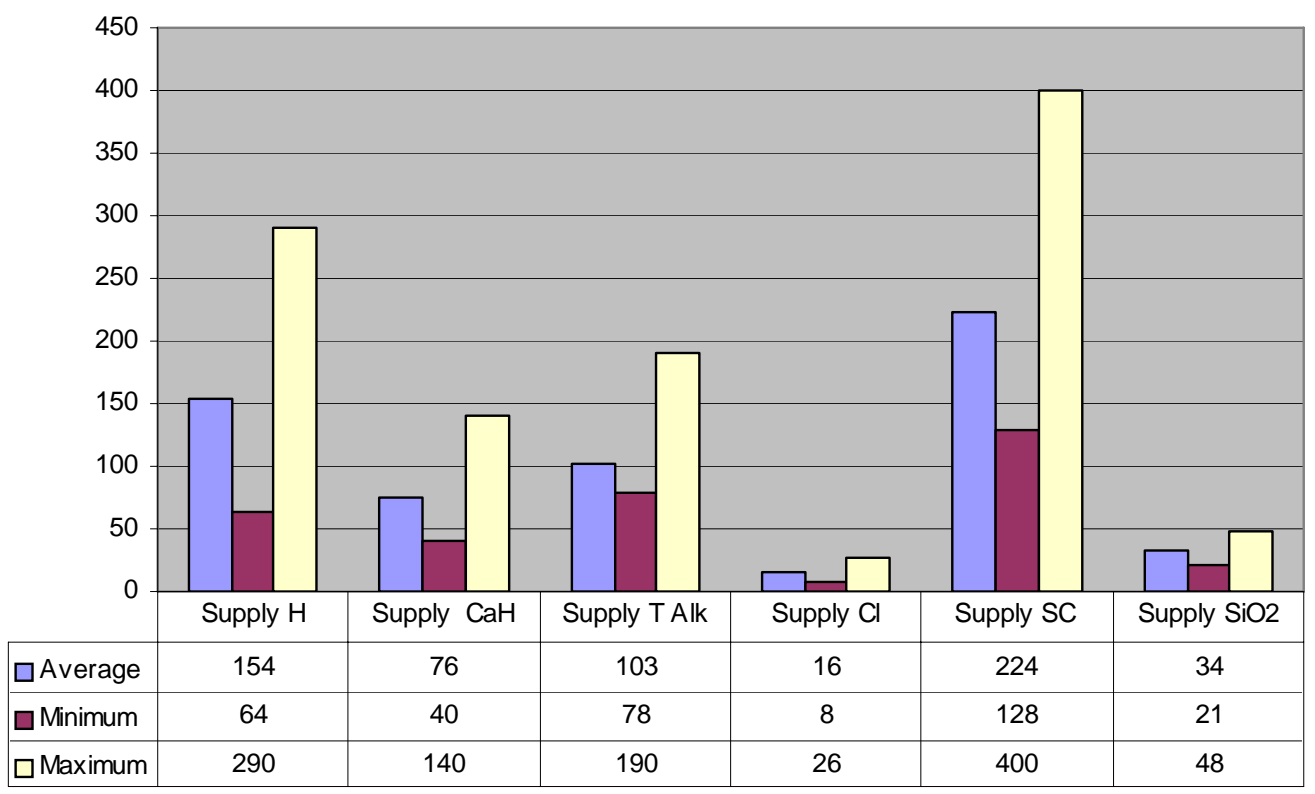

Figure 3. Fort Stewart supply water (dissolved solids, min/max/avg.). 


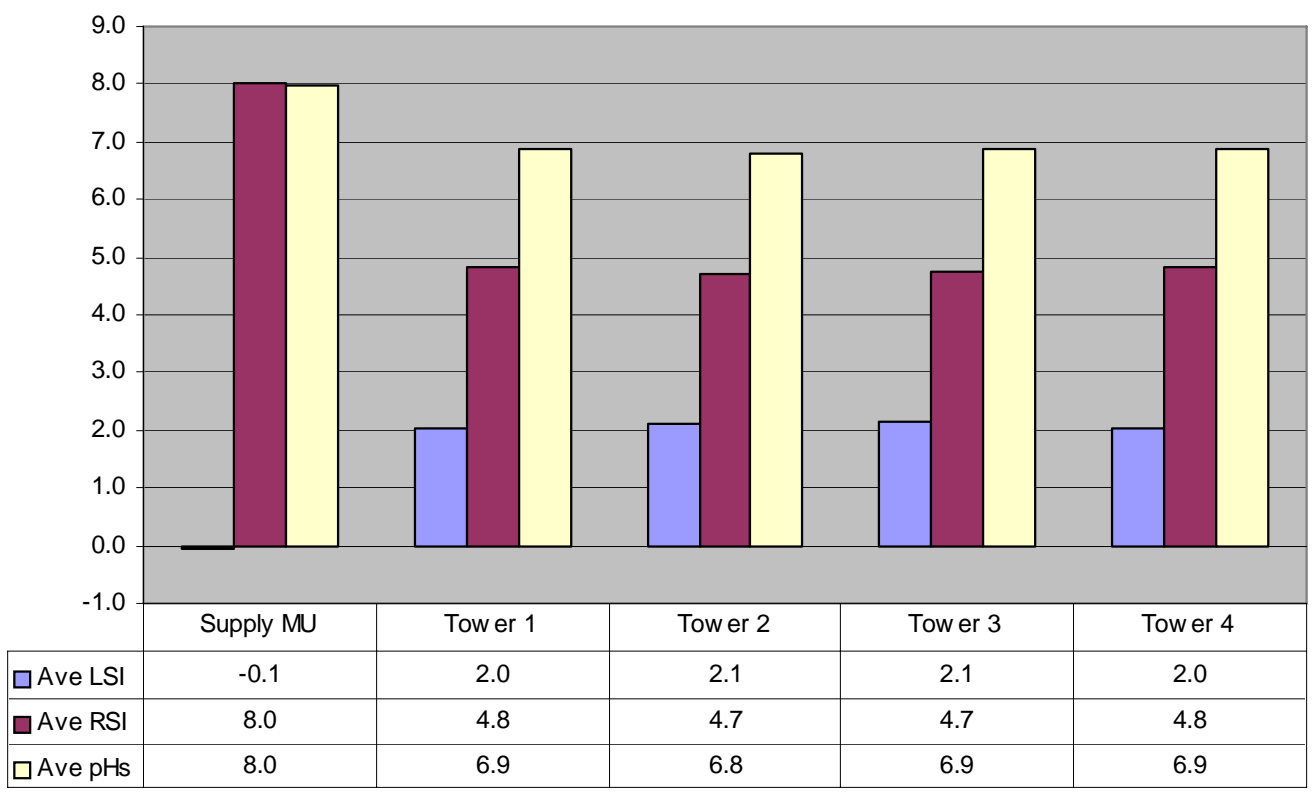

Figure 4. Fort Stewart supply water (avg. dissolved solids, all towers). 


\section{Results}

\subsection{Cooling Tower Analyses}

Fort Hood cooling tower water control has been very good. Changes were generally the result of biocide programming to improve biocide effectiveness (Figure 5). Fort Stewart tower residuals reflect significant fluctuation, primarily due to changes in the makeup supply (Figure 6). However, the advanced automation equipment did a very good job in maintaining established conductivity levels.

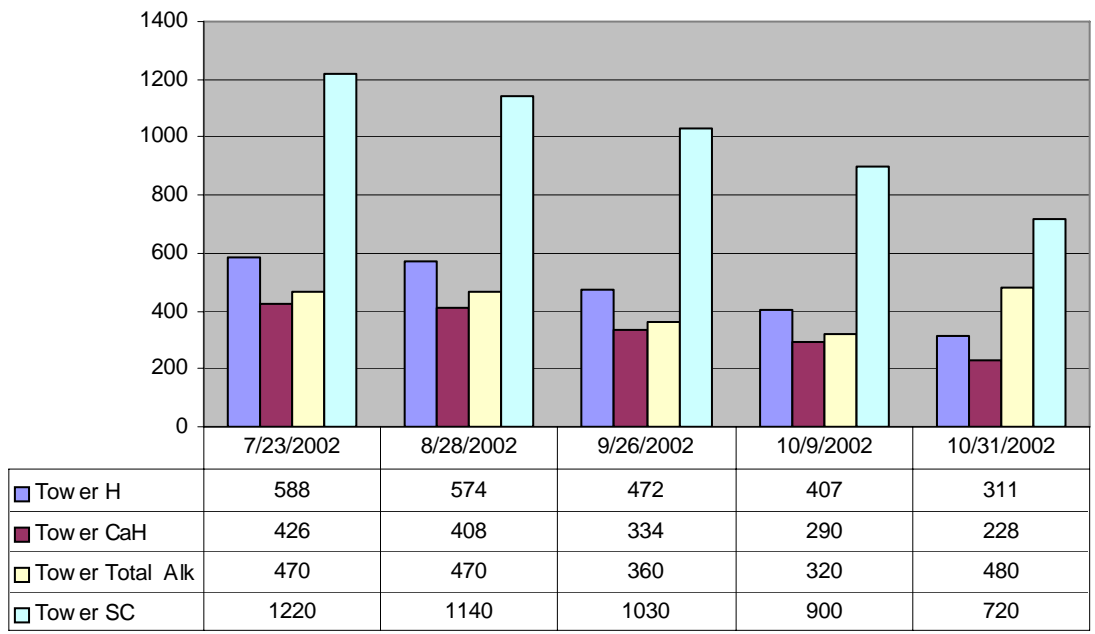

Figure 5. Laboratory results for the Fort Hood cooling towers.

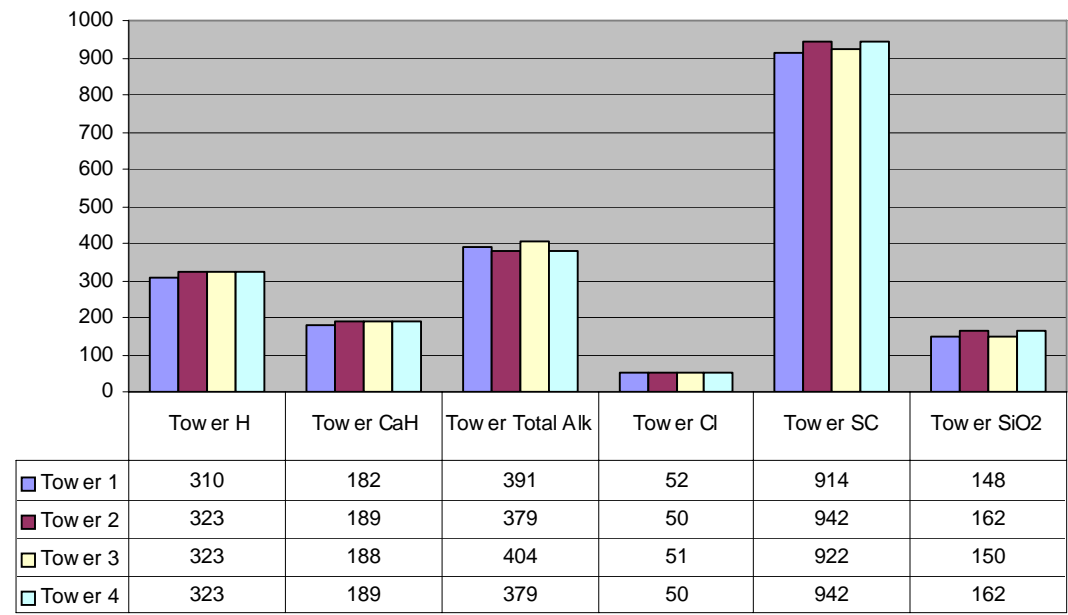

Figure 6. Field analysis for the Fort Stewart cooling towers. 


\subsubsection{Scale Control}

The concentration of the scale inhibitor is monitored by way of the molybdate residual, recommended at 0.5 to 0.75 parts per million (ppm) Mo. This corresponds to 100 to $150 \mathrm{ppm}$ total treatment. Figures 7 and 8 show the excellent chemical molybdate control at both facilities.

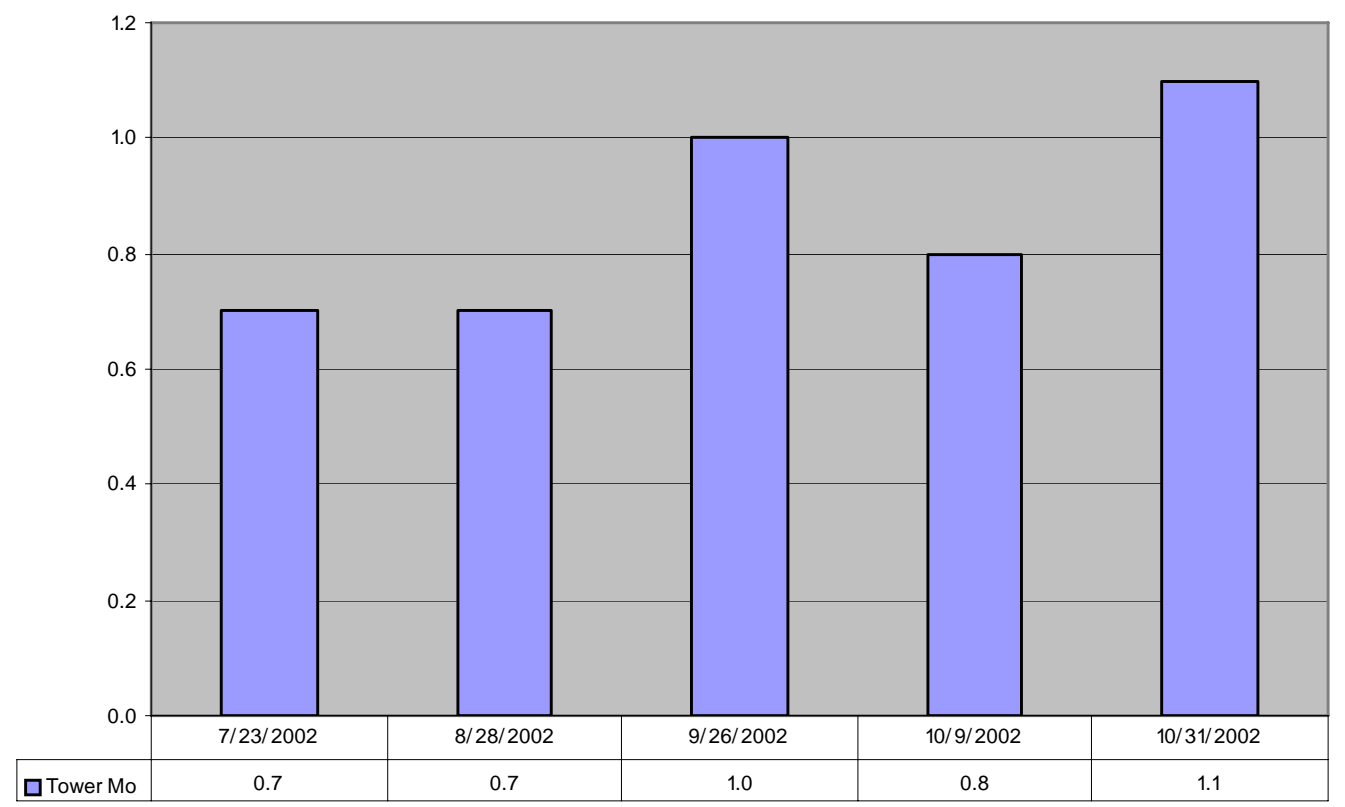

Figure 7. Molybdate analysis of the Fort Hood cooling tower.

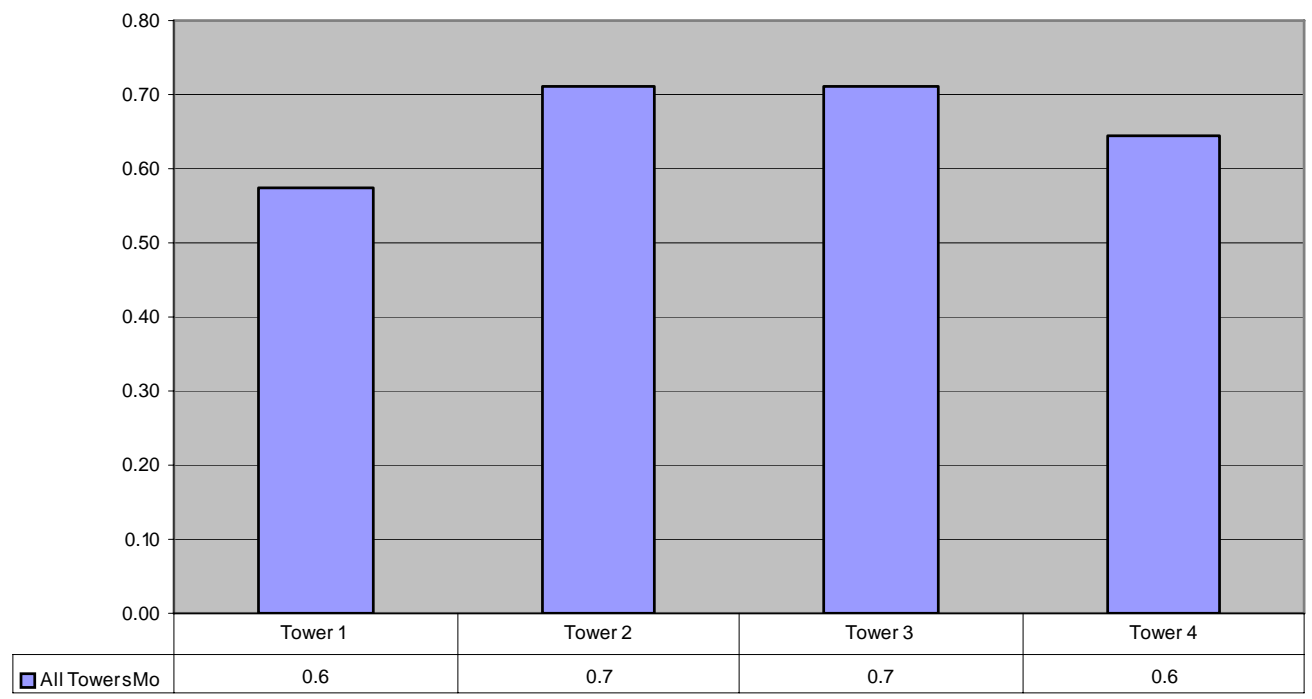

Figure 8. Average molybdenum for all towers at Fort Stewart. 
Another factor in the scale control process is the control of dissolved solids. Without dissolved solids control (specific conductivity), the solubility of specific ions is exceeded. When this occurs, deposition will result, even with proper chemical levels. Again Figures 9 and 10 show that the automation has provided good overall control. In addition to the specific conductivity overview, some supply waters contain an abnormal amount of calcium, total alkalinity, or silica. Also, where sulfuric acid is used for $\mathrm{pH}$ control, consideration must be given to the sulfate content.

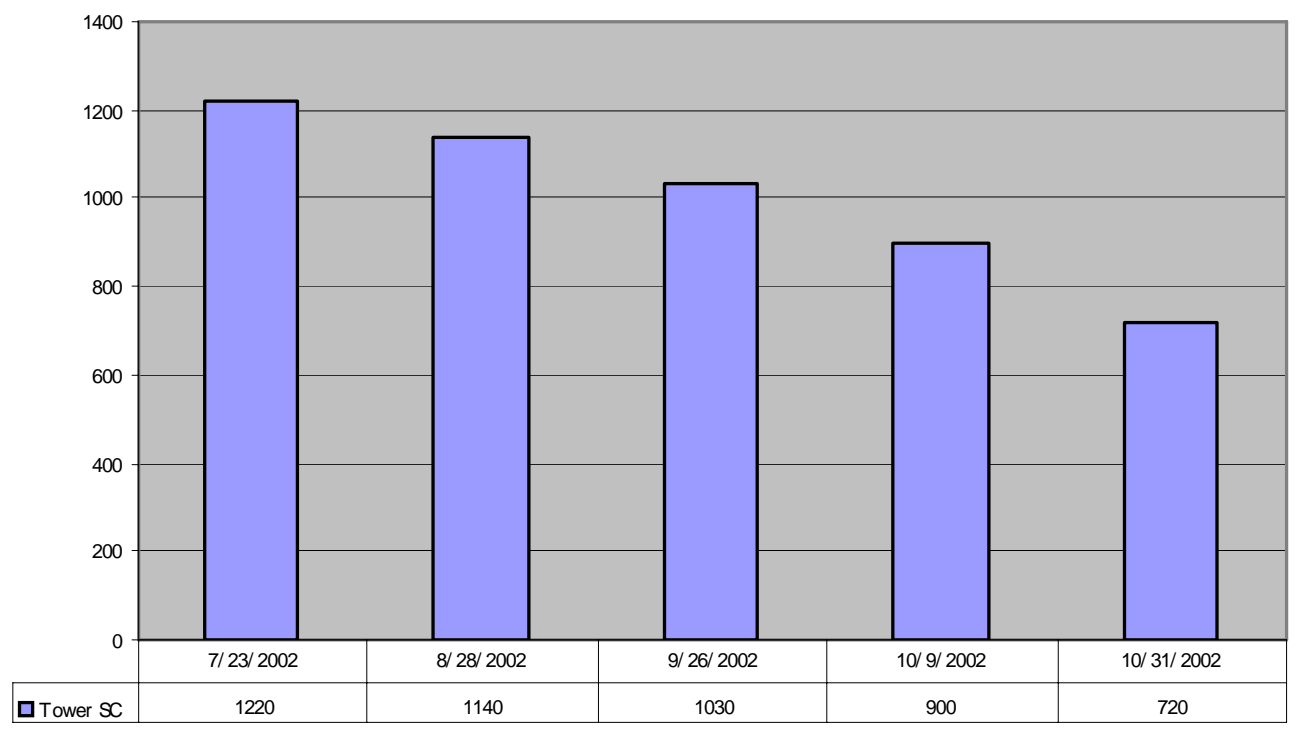

Figure 9. Cooling tower conductivity at Fort Hood.

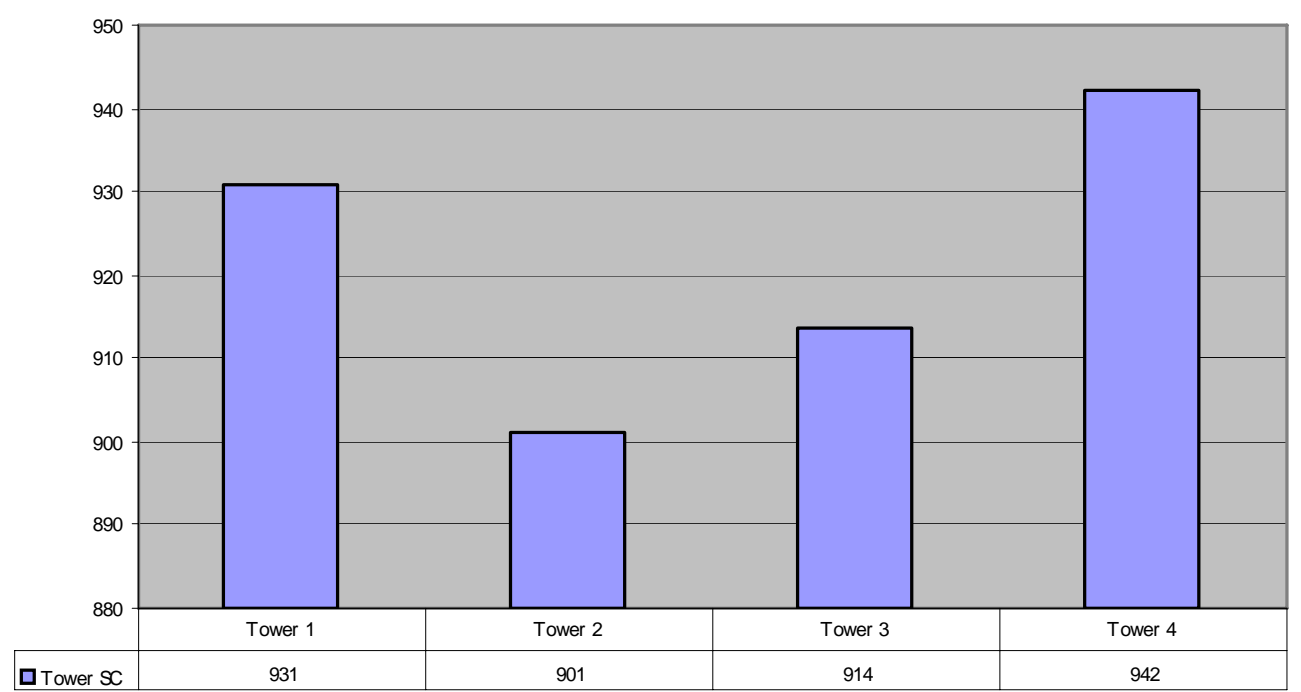

Figure 10. Average conductivity of all cooling towers at Fort Stewart. 
In a non-acid program, the combined total of calcium ions and alkalinity (carbonate, bicarbonate, and hydroxide ions) should not exceed 900 ppm. The exception to this would be when silica levels are high, such as at Fort Stewart. The absolute maximum level of silica in cooling towers is 180 ppm, with control levels normally established at $150 \mathrm{ppm}$ to provide some safety margin. A calcium silicate deposit, which was noted with the initial deposit, is not very responsive to the typical sulfamic or hydrochloric acid flush. If the thickness of the deposit is extensive, only hydrofluoric acid will solubilize the calcium silicate, and this acid is extremely dangerous to use.

Deposition in heat exchangers is not only a burden to mechanical maintenance personnel, but is also very costly as deposits decrease the heat transfer process and this increases energy consumption.

\subsubsection{Cycles of Concentration}

As water evaporates in the cooling process, the minerals remain. This accumulation of minerals, when compared to the minerals in the supply water, is referred to as "cycles of concentration." The comparison of total hardness, calcium hardness, total alkalinity, chlorides, specific conductivity, total dissolved solids (TDS), and silica (Fort Stewart only) in the tower water, when divided by the same element in the supply water, yields the "cycles of concentration" shown in Figures 11 and 12.

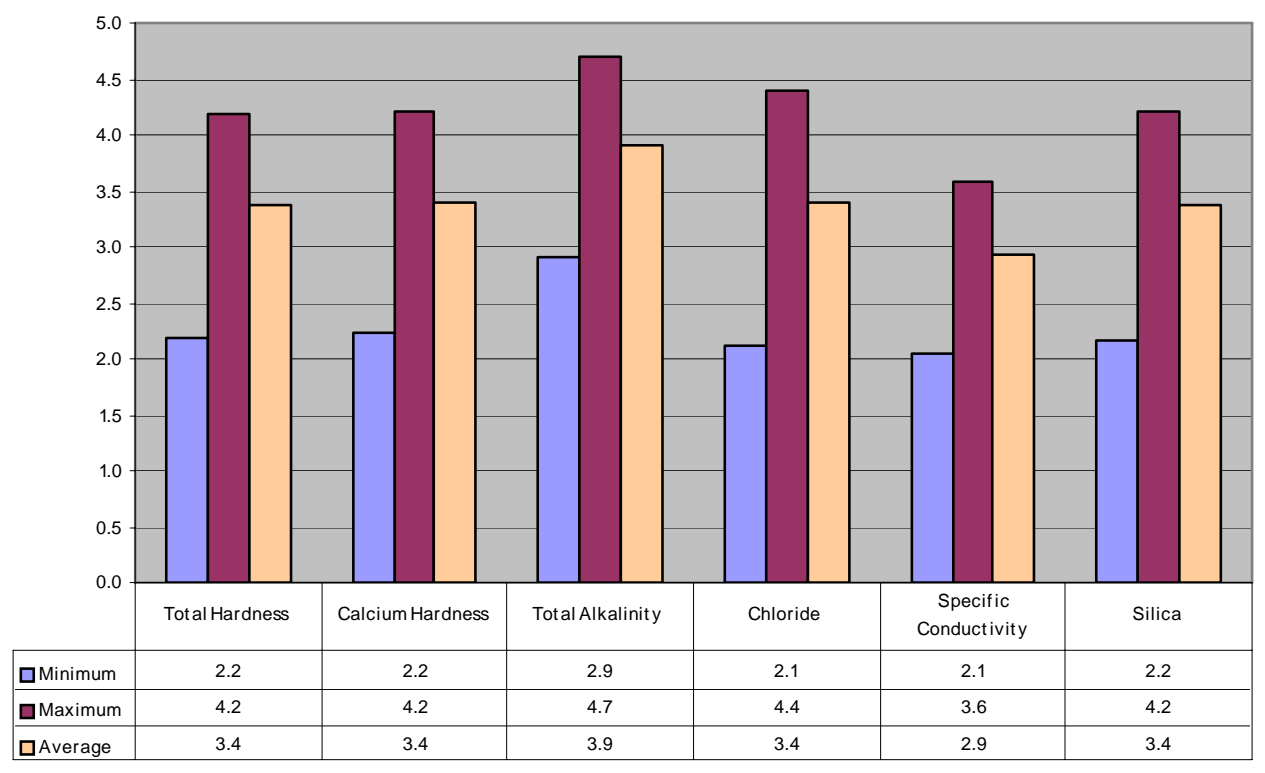

Figure 11. Cycles of concentration at Fort Hood. 


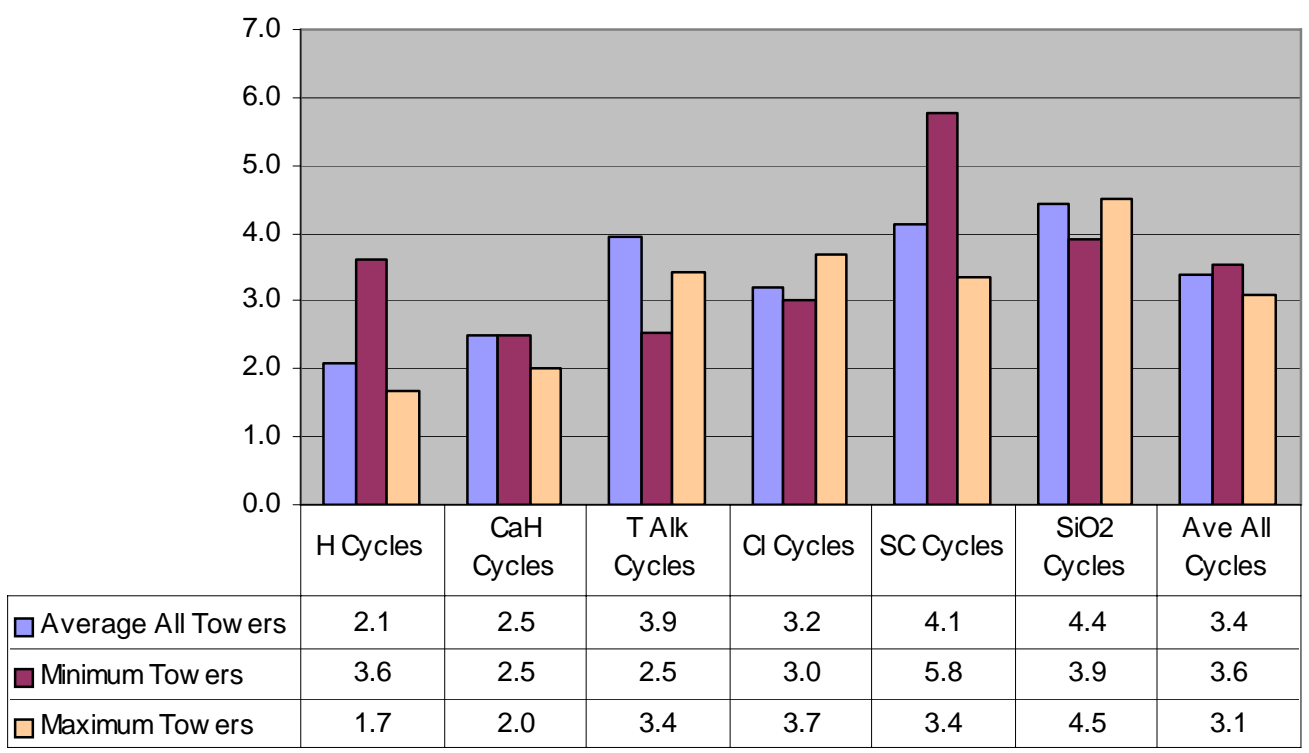

Figure 12. Cycles of concentration for all towers at Fort Stewart.

As previously mentioned, there were concerns about silica levels in the cooling water. With the change in supply water conductivity, hardness, and silica, it was necessary to maintain lower conductivity residuals in the cooling towers than would normally be expected. Since it was known that deposition of silica had previously been a primary element in the composition, researchers did not want to allow the silica residual to exceed 150 ppm. For the most part, the automatic "bleed and feed" system provided the control needed to operate within these operating parameters. Figure 13 shows the average silica levels for each tower at Fort Stewart.

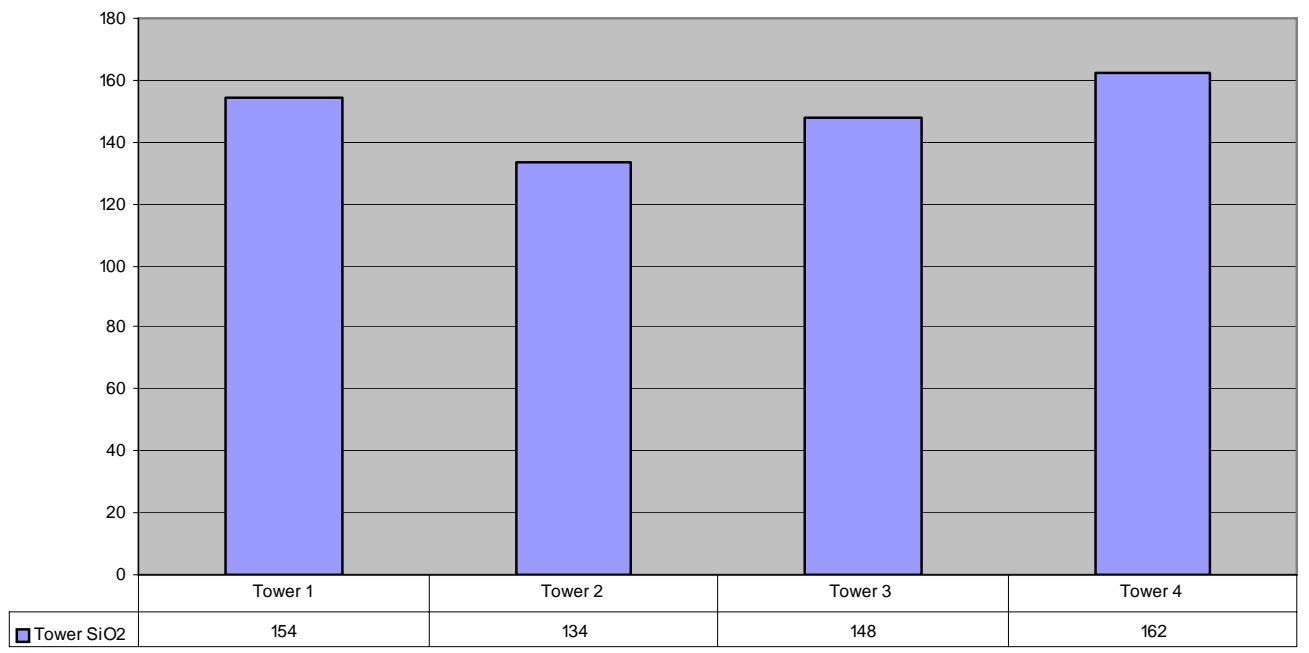

Figure 13. Average silica for all towers at Fort Stewart. 


\subsubsection{Bio Control}

The effective control of microbiological organisms is a very important part of the water treatment program. Biological control primarily consists of bacteria and algae control. It is rare that one material alone can control both classes of organisms.

In the project evaluation process, a decision was made to use THPS (Garratt-Callahan formulation G-C 3004) on a "standalone" basis, out of a concern that the typical dual biocide approach would make it difficult to evaluate the THPS' performance. Microbial monitoring for algae was done visually (using pictures), and for bacteria using Sani-Check BF dip slides. Although a measurement of 500,000 organisms/ ml or less is considered "good control" of aerobic bacteria is, and 100,000 organisms/ ml or less is considered "excellent control," the only truly acceptable count for anaerobic bacteria is zero organisms/ $\mathrm{ml}$ (which is tested with the Sani-Check anaerobic kit). Tables 2 and 3 list the results of the bacteria tests at Fort Hood and Fort Stewart. The evaluation process also included physical inspection of the cooling towers, with pictures, for algae control.

The THPS product was classified as a broad spectrum material, used primarily to control aerobic and anaerobic bacteria. For the most part, the material was very effective in the control of bacteria. Graphs in Figures 14 through 17 illustrate the bacteria effectiveness of THPS at Fort Stewart. Similarly, Figure 18 shows bacteria control at the Fort Hood cooling tower.

Recall that bacteria counts show only planktonic (free-floating) bacteria. Sessile bacteria are those attached to the tower, and can outnumber the planktonic bacteria. Bacteria tests are very useful in showing general trends of bio control. While not a precise method of measurement, it is generally accepted that low bacteria counts indicate a cleaner and safer system than those that show high bacteria levels. Figures 19 and 20 reflect minimal algae control at Fort Hood and Fort Stewart.

Table 2. Bacteria bio count (Fort Hood).

\begin{tabular}{|l|c|c|}
\hline Date & $\begin{array}{c}\text { Aerobic } \\
\text { Bacteria }\end{array}$ & $\begin{array}{c}\text { Anaerobic } \\
\text { Bacteria }\end{array}$ \\
\hline 10 July 2002 & $10^{4}$ & 0 \\
\hline 31 July 2002 & $10^{3}$ & 0 \\
\hline 8 August 2002 & $10^{3}$ & 0 \\
\hline 20 August 2002 & $10^{3}$ & 0 \\
\hline
\end{tabular}




\begin{tabular}{|l|c|c|}
\hline Date & $\begin{array}{c}\text { Aerobic } \\
\text { Bacteria }\end{array}$ & $\begin{array}{c}\text { Anaerobic } \\
\text { Bacteria }\end{array}$ \\
\hline 27 August 2002 & $10^{4}$ & 0 \\
\hline 5 September 2002 & $10^{5}$ & 0 \\
\hline 11 September 2002 & $10^{5}$ & 0 \\
\hline 18 September 2002 & $10^{4}$ & 0 \\
\hline 26 September 2002 & $10^{3}$ & 0 \\
\hline 2 October 2002 & $10^{3}$ & 0 \\
\hline 9 October 2002 & $10^{4}$ & 0 \\
\hline 16 October 2002 & $10^{4}$ & 0 \\
\hline 23 October 2002 & $10^{5}$ & 0 \\
\hline 31 October 2002 & $10^{3}$ & 0 \\
\hline 5 November 2002 & $10^{3}$ & 0 \\
\hline 12 November 2002 & $10^{4}$ & 0 \\
\hline 20 November 2002 & $10^{3}$ & 0 \\
\hline 27 November 2002 & $10^{3}$ & 0 \\
\hline
\end{tabular}

Table 3. Aerobic bacteria bio count (Fort Stewart).

\begin{tabular}{|c|c|c|c|c|}
\hline Date & Tower 1 & Tower 2 & Tower 3 & Tower 4 \\
\hline 19 July 2002 & & $10^{3}$ & & \\
\hline 4 August 2002 & & & & $10^{4}$ \\
\hline 9 August 2002 & & & $10^{3}$ & \\
\hline 16 August 2002 & $10^{2}$ & & & \\
\hline 2 September 2002 & & & $10^{3}$ & $10^{2}$ \\
\hline 6 September 2002 & $10^{2}$ & & & \\
\hline 15 September 2002 & $10^{2}$ & & & \\
\hline 23 September 2002 & & & & $10^{3}$ \\
\hline 1 October 2002 & $10^{2}$ & & $10^{3}$ & \\
\hline 8 October 2002 & $10^{2}$ & $10^{2}$ & & \\
\hline 18 October 2002 & & & & $10^{2}$ \\
\hline 25 October 2002 & & $10^{3}$ & & \\
\hline 1 November 2002 & 102 & & & \\
\hline 8 November 2002 & & $10^{2}$ & & \\
\hline 15 November 2002 & $10^{3}$ & & & \\
\hline
\end{tabular}




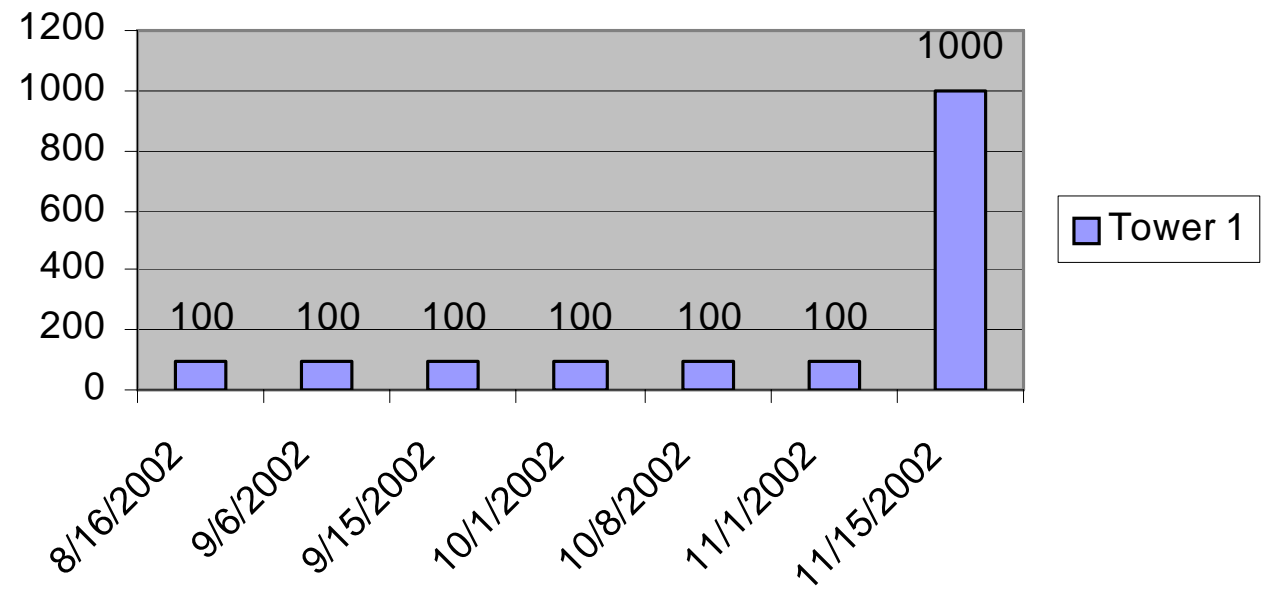

Figure 14. Fort Stewart - Tower 1.

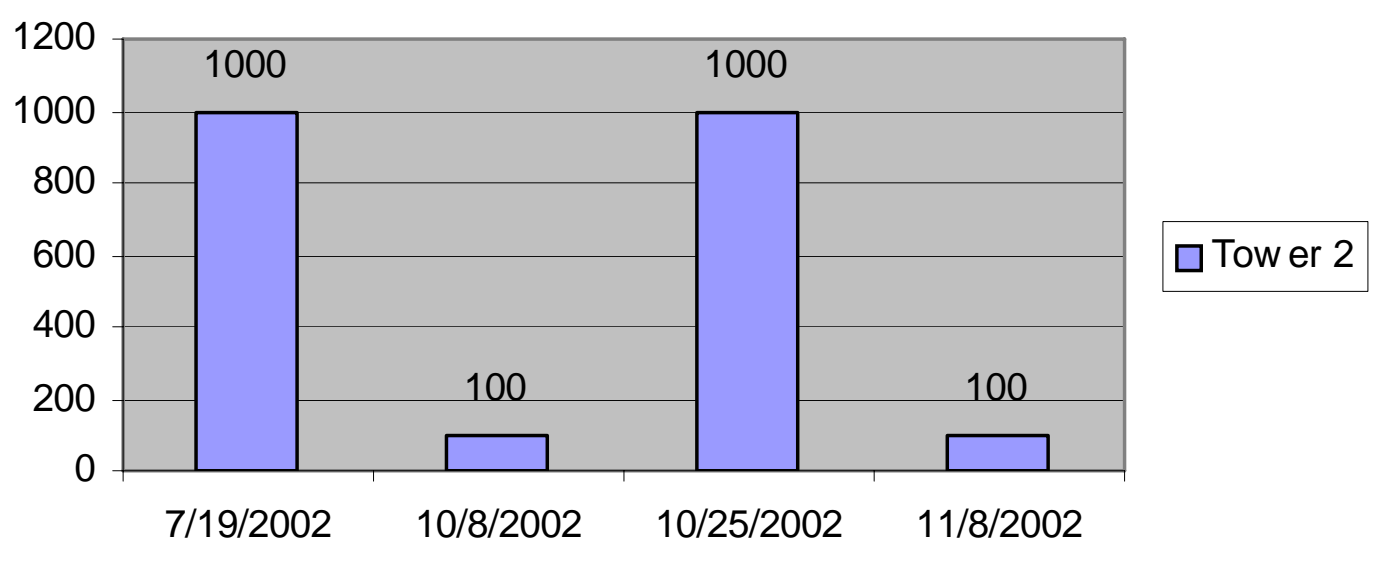

Figure 15. Fort Stewart - Tower 2.

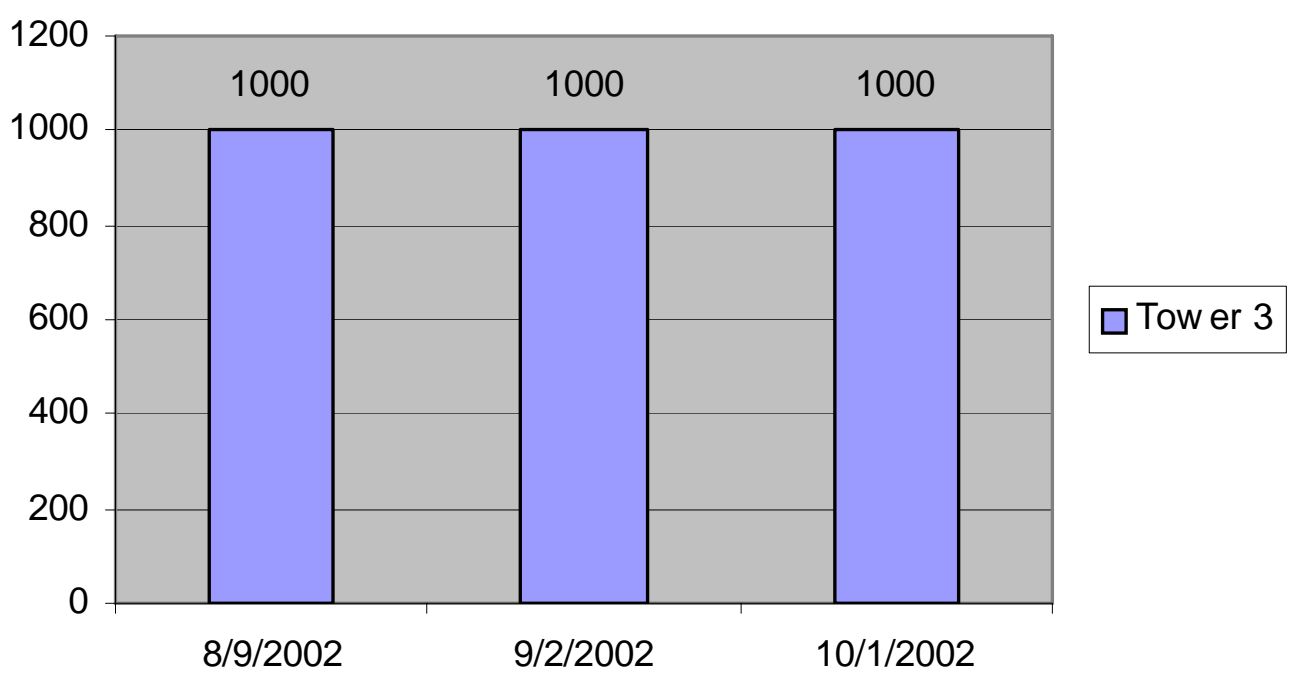

Figure 16. Fort Stewart - Tower 3. 


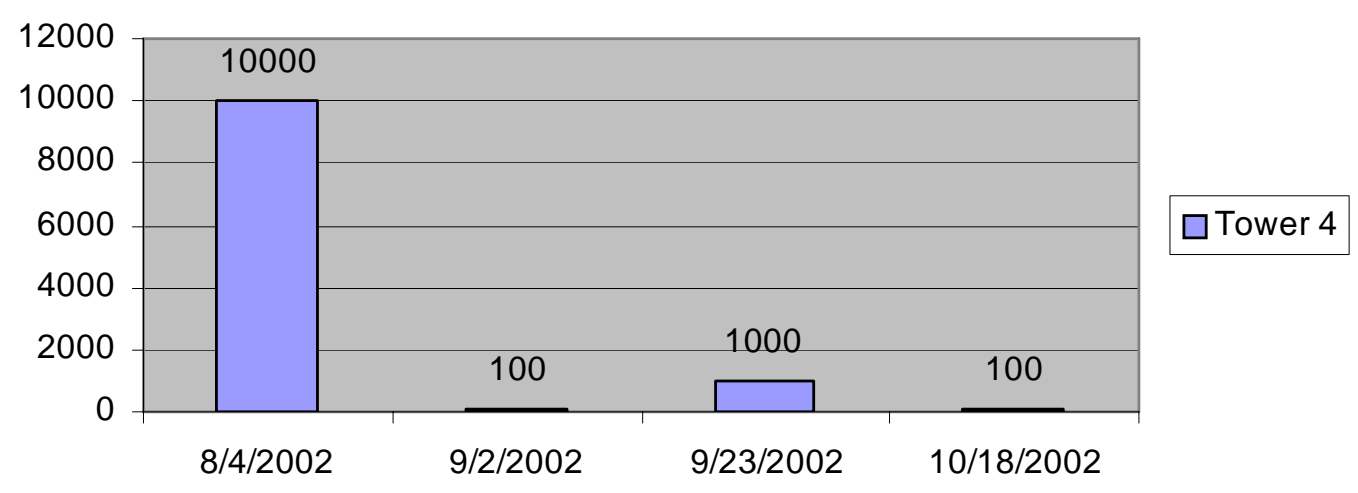

Figure 17. Fort Stewart - Tower 4.

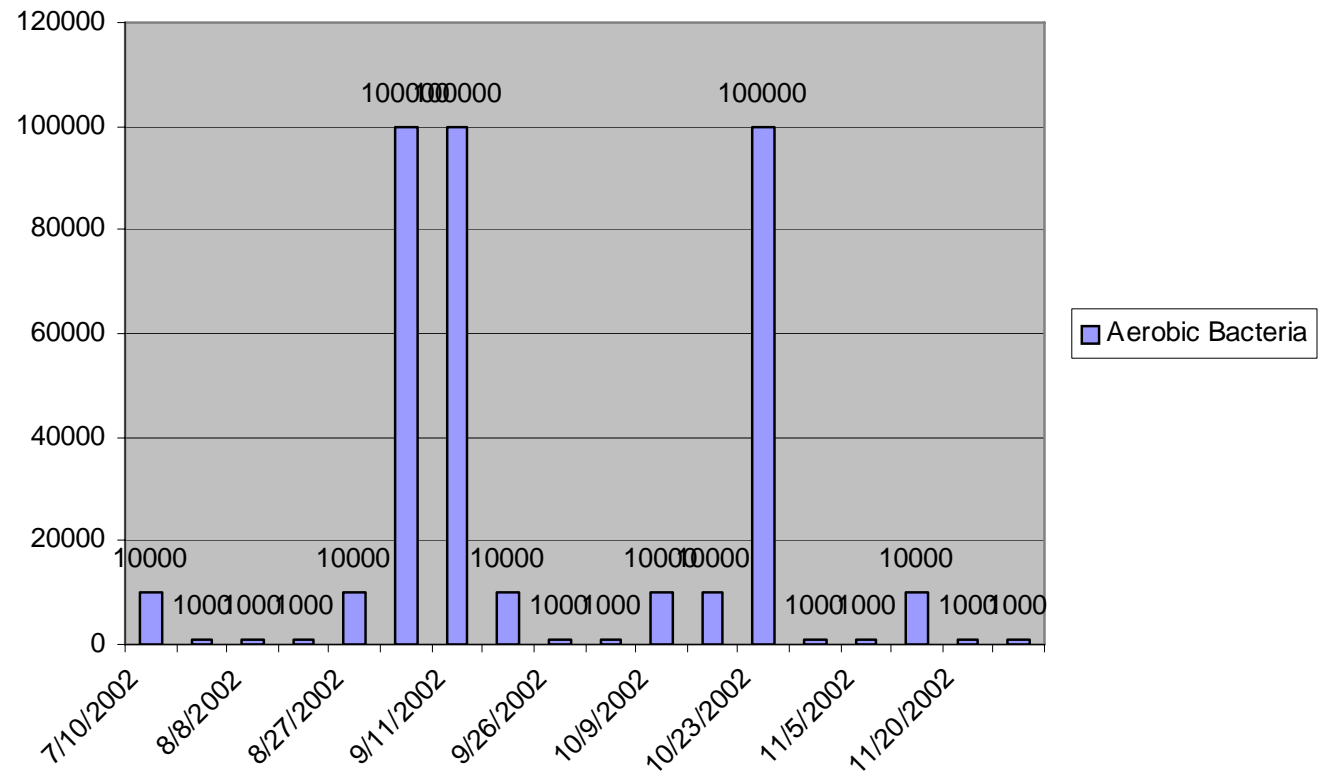

Figure 18. Fort Hood aerobic bacteria. 


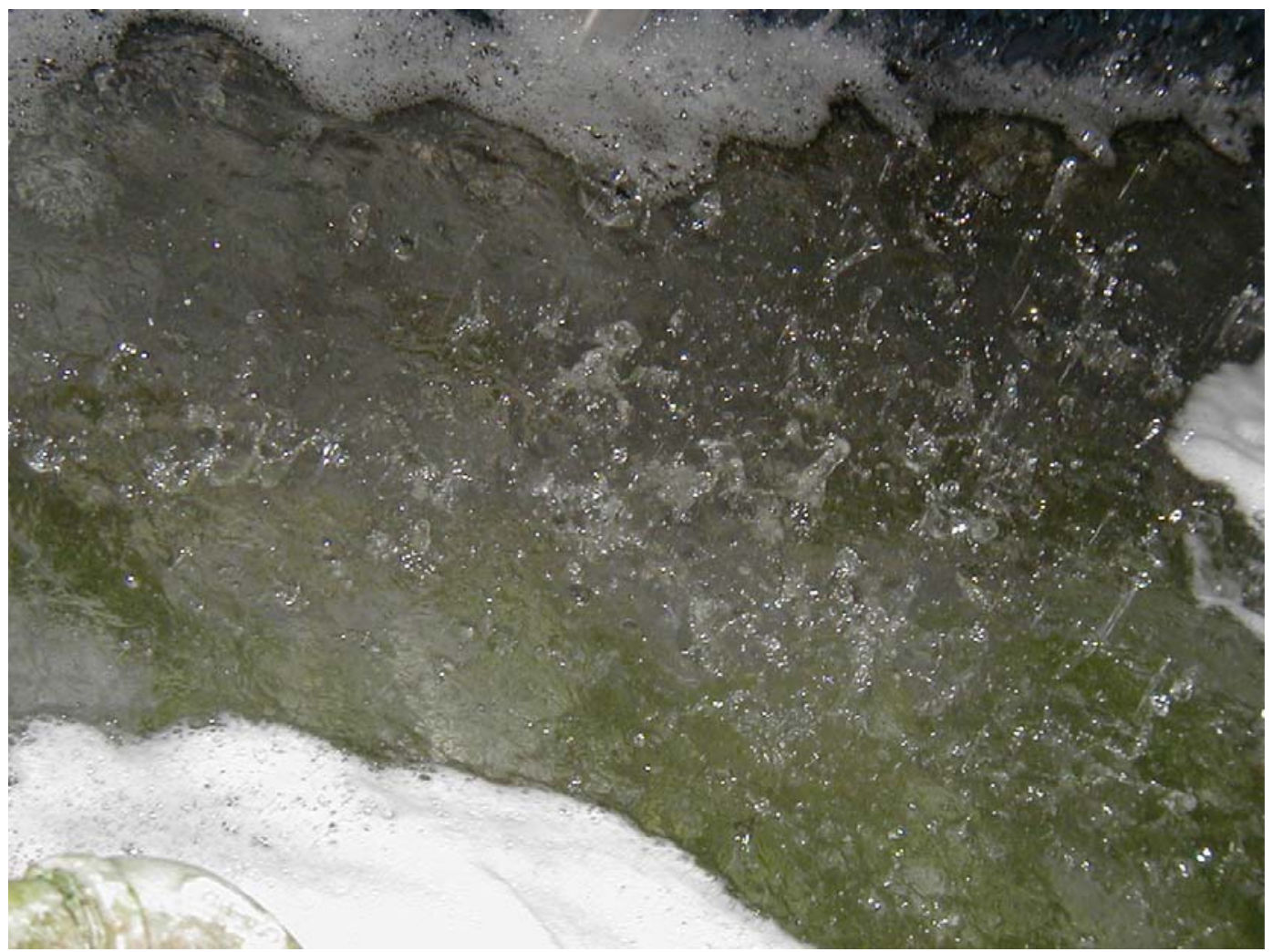

Figure 19. Fort Hood Sump.

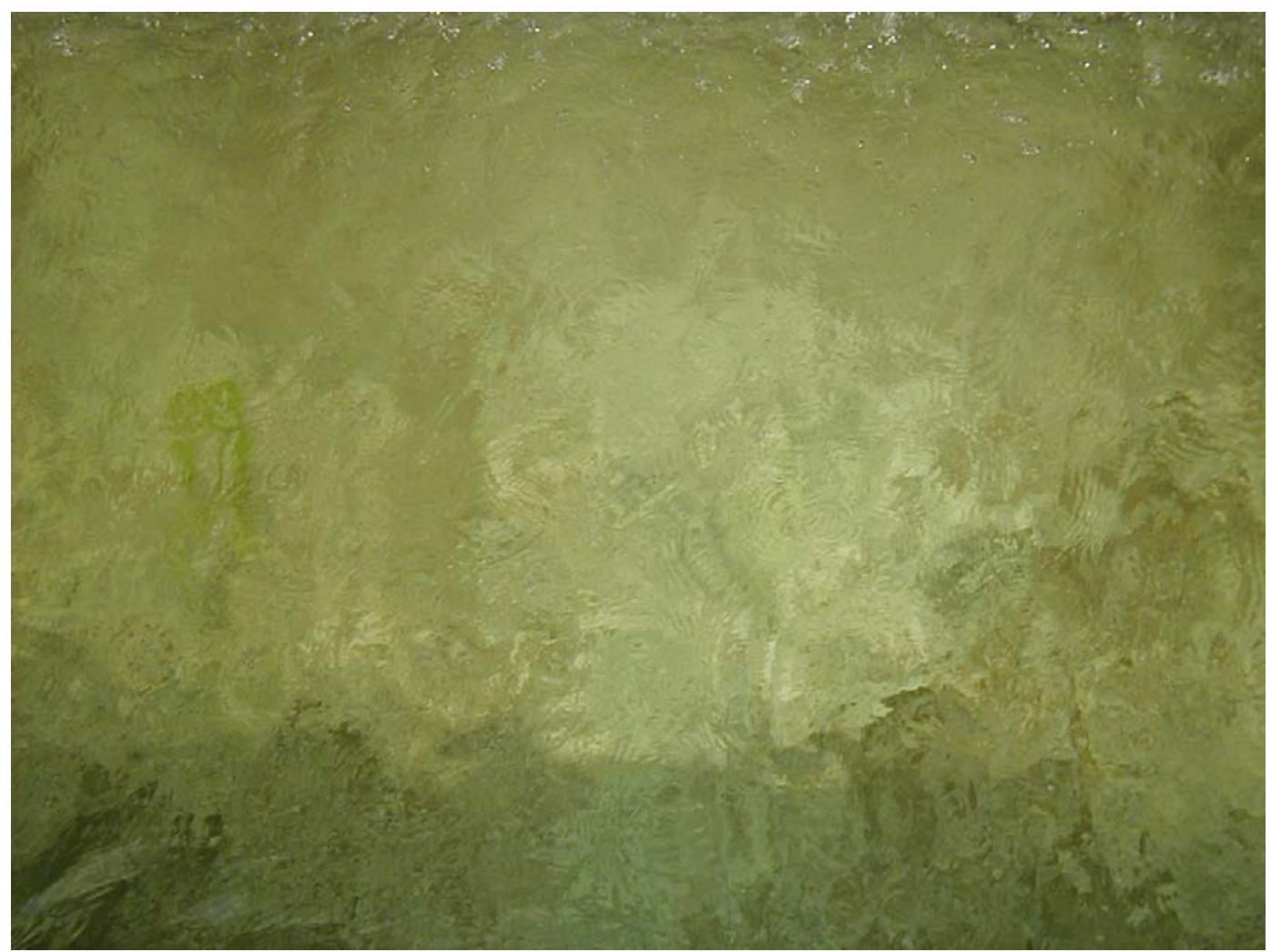

Figure 20. Fort Stewart sump. 


\subsection{Steam Boiler Condensate}

A biodegradable filming inhibitor, formulated as Garratt-Callahan 4055, was applied to the steam line for corrosion control. Figure 21 shows the tight film formation.

\subsection{Corrosion Data}

Corrosion is a natural electro-chemical process that can attack any metal or alloy under the right conditions. The Illinois State Water Survey took and verified corrosion measurements in the cooling tower water and in the boiler condensate with the use of corrosion coupons.

Measurements were also taken with a field corrator, which measures overall corrosion rates and pitting corrosion rates. Corrator probes, sometimes referred to as "automatic coupons" are used to measure loss of probe metal by measuring their change in resistance. As with coupons, probes must be in the system for a period of time to allow the probe to corrode so that accurate measurements can be made.

Figure 22 shows the corrosion rate of the cooling tower water and condensate at Fort Hood and Figure 23 reflects the corrosion rate for the condensate system at Fort Stewart. Overall, an average of 3 mils per year is considered "good corrosion control."
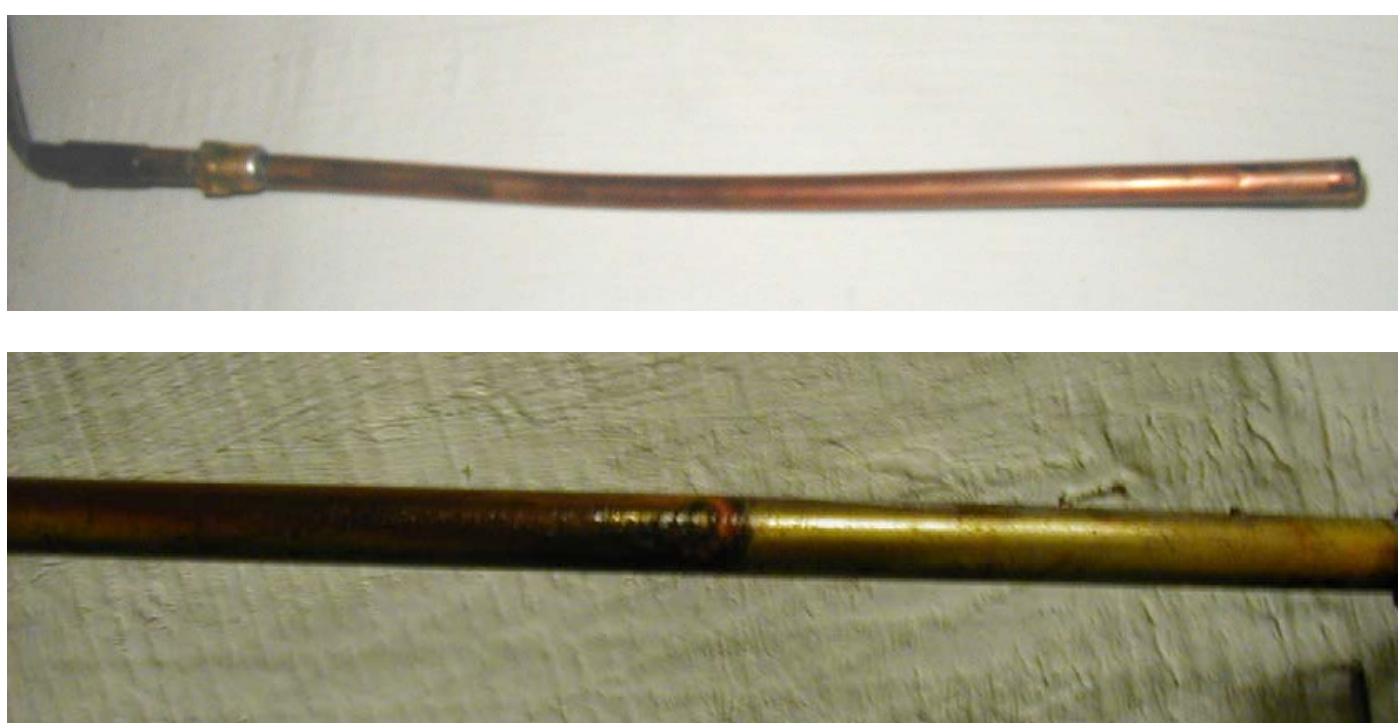

Figure 21. Filming inhibitors. 


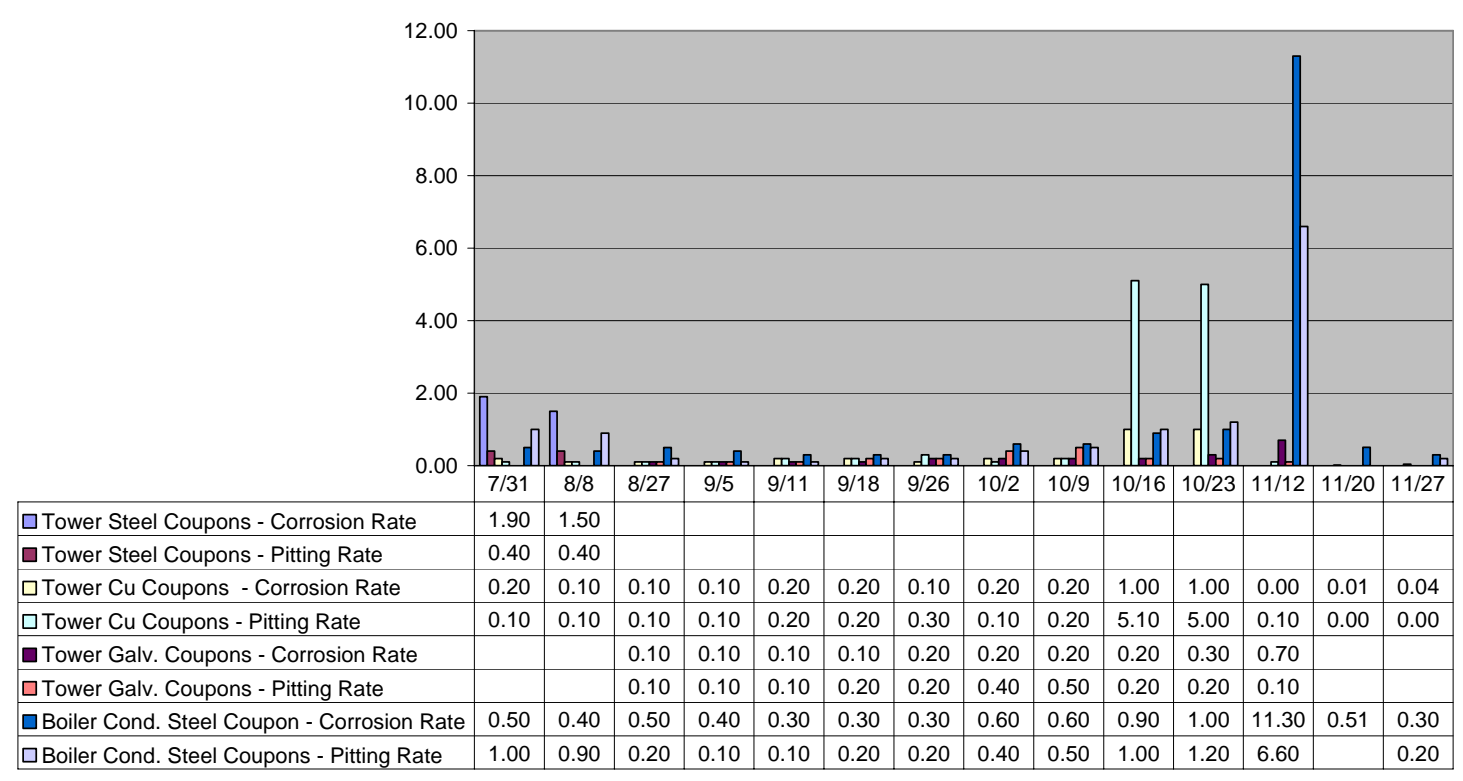

Figure 22. Corrator results and analyses for cooling towers and condensate at Fort Hood.

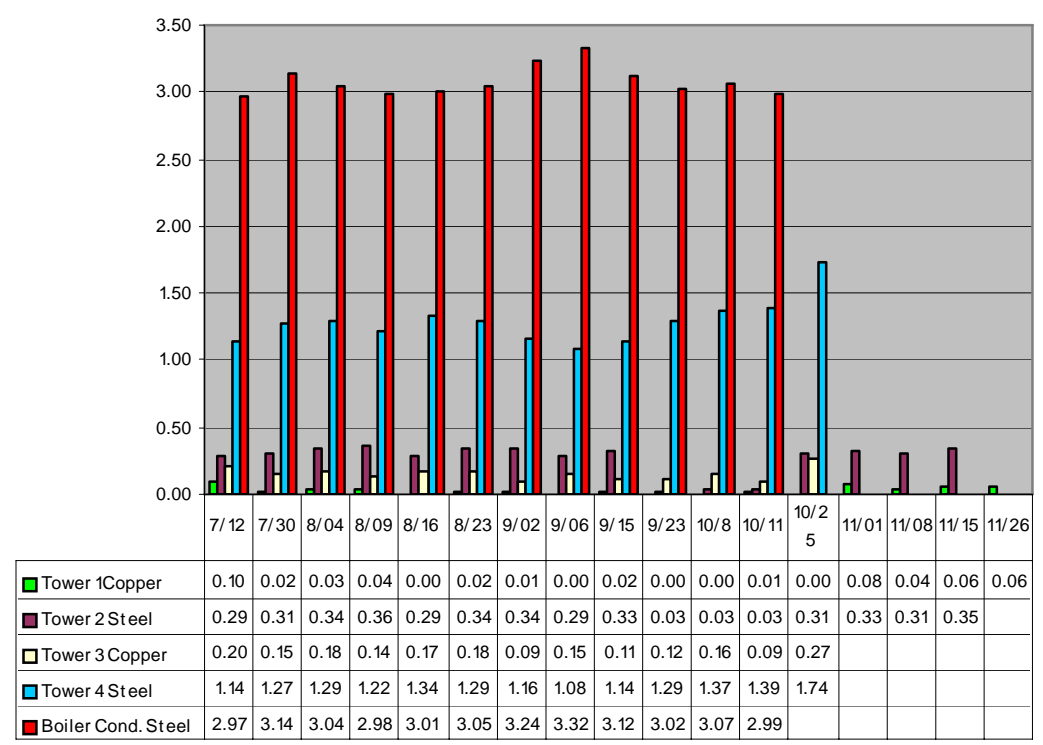

Figure 23. Fort Stewart Corrator Results.

The dosage was determined to be the key factor in the variation of corrosion results. When the ethoxalated soya amine approached 2 parts per million, the corrosion rate increased significantly. It is suggested that the material be applied at 3 parts per million of active ingredient. (A 10-percent solution would require a dosage of $30 \mathrm{ppm}$.)

Figure 24 shows a typical corrosion coupon installation and corrator. Note that the readings are only accurate when the probe tips are completely 
submerged in water. Sometimes this does not occur in the condensate lines. Also (very important), when taking readings with the corrator, if the pitting numbers exceed the general corrosion rate, the pitting numbers are no longer accurate.

\subsection{Improved Automation Control}

The advanced fully automated equipment represents a significant improvement in the application of water treatment products. The use of this state-of-the-art technology also significantly improves the safety of handling chemicals. Communication capabilities provide the opportunity to remotely monitor system performance, gather system data, and adjust operating parameters. Overall performance was very good.

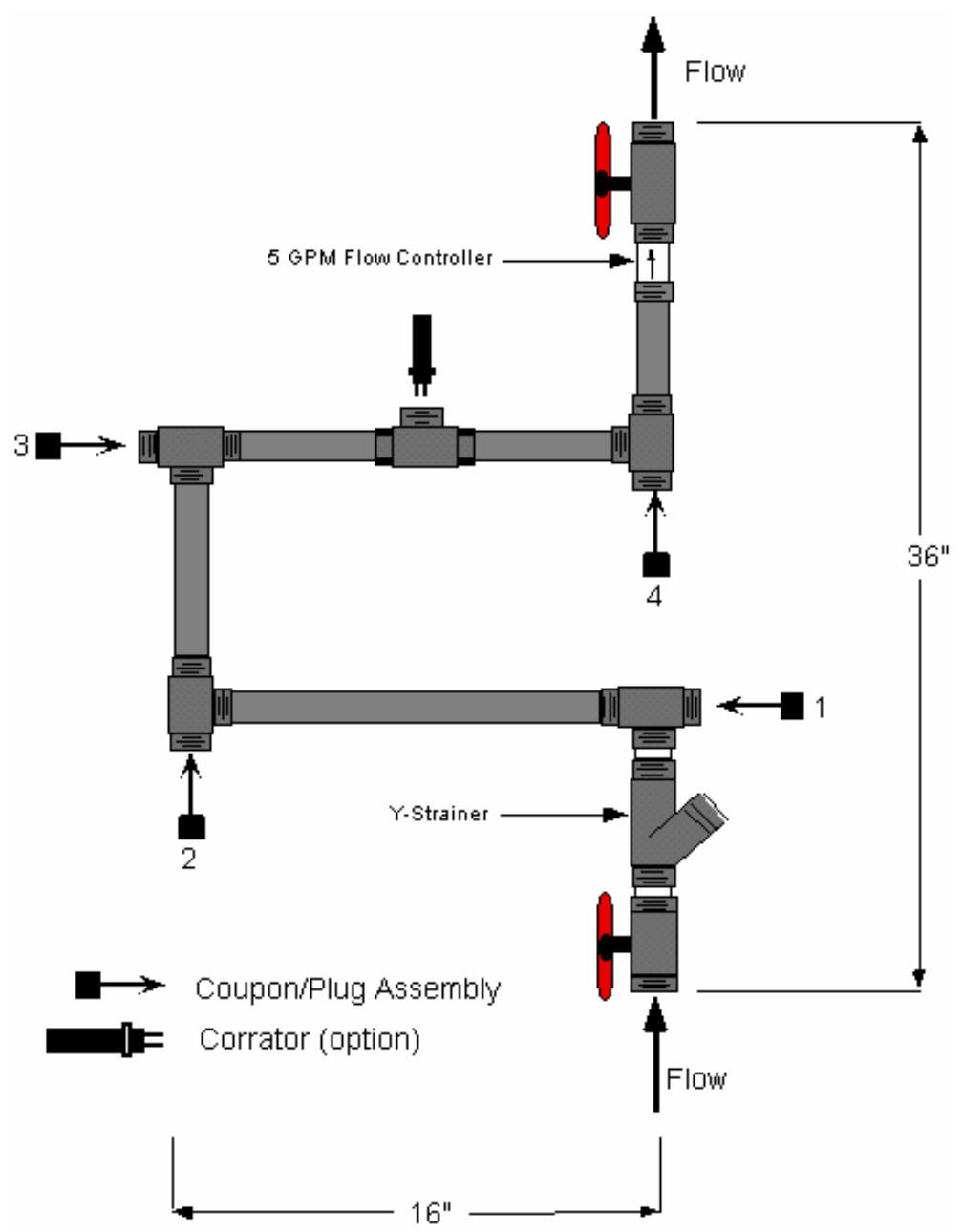

Figure 24. Corrator probe installation. 


\section{Conclusions and Recommendations}

This study demonstrated the effectiveness of three green chemical formulations for the control of corrosion, scale, and microbiological growth in heating and cooling systems. Compared to the traditional treatments, these formulations have properties such as biodegradability that make them more friendly to the environment. The implementation of these formulations in cooling towers and steam distribution lines at Fort Hood and Fort Stewart showed that these formulations can perform well. Specific recommendations for each formulation follow.

\subsection{Cooling Water Inhibitor}

\subsubsection{Conclusions}

The application of the polyaspartate (PASP) inhibitor blend maintained the operating performance of the equipment unchanged. This study found that the product had good dispersion qualities, and that it offered the advantage of being biodegradable. A few tests were found with elevated copper residuals that may or may not be influenced by the PASP material.

When the condensers were opened at the end of the project period at Fort Hood and at Fort Stewart, the heat exchanger tubes at Fort Hood were found to be very clean and at Fort Stewart as good as, or better than, previous inspections using conventional water treatment chemicals.

\subsubsection{Recommendations}

Additional testing to optimize dosage is recommended with future applications.

\subsection{Cooling Water Biocide}

\subsubsection{Conclusions}

The biocide application of tetrakis hydroxymethyl phosphonium sulfate (THPS) was found to be particularly effective against bacteria; it was found to provide good control of both aerobic and anaerobic bacteria. 


\subsubsection{Recommendation}

The recommended dosage for THPS of $360 \mathrm{ppm}$ is higher than some of the other non-oxidizing biocides. Since THPS had limited success with algae control, this study recommends supplementing the use of THPS with an alternate non-oxidizing algaecide.

\subsection{Steam Line Treatment}

\subsubsection{Conclusions}

The filming inhibitor used for condensate corrosion control, an ethoxalated soya amine, showed considerable promise due to the ease of application and strong film formation. The additional oxygen protection provided by a film forming material (as compared to conventional neutralizing amines) is a very important characteristic of this product since it can still be effective when steam boilers are put on stand-by, with the resulting significant decrease in steam line temperature and pressure. Overall corrosion data was good, although there were spikes when the dosage was not maintained and when the condensate line was not full (at which time the corrator tip was not totally sub-merged in condensate). The advantage of this product, as compared to a neutralizing amine, is the additional protection against oxygen corrosion. In addition, this product is not a suspected carcinogen like some neutralizing amines.

\subsubsection{Recommendation}

It is recommended that users of this product maintain a residual of 2-3 ppm active ingredient for effective corrosion inhibition. 


\section{Acronyms and Abbreviations}

$\begin{array}{ll}\text { Term } & \text { Spellout } \\ \text { ANSI } & \text { American National Standards Institute } \\ \text { AOX } & \text { adsorbable organically bound halogens } \\ \text { BF } & \text { bacteria and fungi } \\ \text { BZT } & \text { benzotriazole } \\ \text { CERL } & \text { Construction Engineering Research Laboratory } \\ \text { DO } & \text { Dissolved Oxygen } \\ \text { EPA } & \text { Environmental Protection Agency } \\ \text { ERDC } & \text { Engineer Research and Development Center } \\ \text { ERDC-CERL } & \text { Engineer Research and Development Center, Construction Engineering } \\ & \text { Research Laboratory } \\ \text { FORSCOM } & \text { U.S. Army Forces Command } \\ \text { HEDP } & \text { 1-Hydroxyethane } \\ \text { HQDA } & \text { Headquarters, Department of the Army } \\ \text { HVAC } & \text { heating, ventilating, and air conditioning } \\ \text { IMA } & \text { Installation Management Agency } \\ \text { ISWS } & \text { Illinois State Water Survey } \\ \text { LSI } & \text { Langlier's Saturation Index } \\ \text { NSN } & \text { National Supply Number } \\ \text { OMB } & \text { Office of Management and Budget } \\ \text { PASP } & \text { polyaspartate } \\ \text { PBTC } & \text { 2-Phosphonobutane-1,2,4-Tricarboxylic Acid } \\ \text { POC } & \text { point of contact } \\ \text { RSI } & \text { Ryznar's Stability Index } \\ \text { SS } & \text { Stainless Steel } \\ \text { TDS } & \text { total dissolved solids } \\ \text { THPS } & \text { tetrakis } \\ \text { TR } & \text { Technical Report } \\ \text { URL } & \text { Universal Resource Locator } \\ \text { USACE } & \text { U.S. Army Corps of Engineers } \\ \text { WWW } & \text { World Wide Web } \\ & \end{array}$




\section{Appendix A: Acknowledgements}

Frank Fehmel, J r. is the Program Director for Trevino Mechanical who directs program work at Fort Hood and who works with Mike Trevino, President of Trevino Mechanical. Trevino Mechanical provides mechanical consulting and coordinates all project tasks. Dave Hurt, Senior Program Manger with Garratt-Callahan Company, and Steve Maloney, GarrattCallahan District Manager, are responsible for Green Chemistry product application and evaluation of both test sites. Hurt is responsible for the documentation and reporting process for this project and all program activities at Fort Hood. Maloney is the Garratt-Callahan "point man" for technical advice and project support.

Fort Stewart POCs were Randy Parks and Fred Cavedo. The GarrattCallahan implementation team at Fort Stewart is Skip Burney (field service), Mike Adams (District Manager), and Donn West (Area Manager). The Fort Hood POC was Barry Sadler. The Garratt-Callahan implementation team at Fort Hood is Dave Hurt, Senior Program Manager, Evan Erickson, service technician who applies all chemicals at Building 36006, Steve Maloney, District Manager, and Mike Wilhite, Area Manager.

Laboratory support and verification includes both the Illinois State Water Survey (ISWS) and the Garratt-Callahan EPA certified Laboratory in Millbrae, CA. Ms. Margaret Scott is responsible for the Garratt-Callahan analytical laboratory. Charles Curtiss is the Water Treatment Specialist and Coordinator of Laboratory Services with the ISWS. As third party verifiers, Charles Curtiss and ISWS Director Kent Smothers provided corrosion coupons and analyses, water analysis, and a full report with additional documentation, serving as project confirmation. 


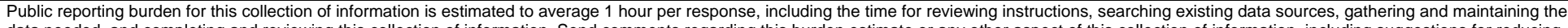

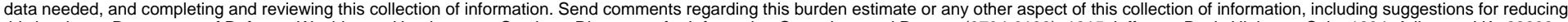

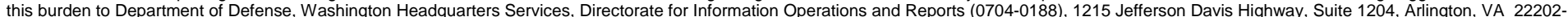

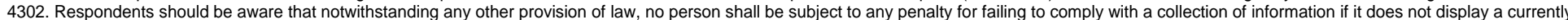
valid OMB control number. PLEASE DO NOT RETURN YOUR FORM TO THE ABOVE ADDRESS.
1. REPORT DATE (DD-MM-YYYY)
2. REPORT TYPE

22-09-2006 Final

4. TITLE AND SUBTITLE

Green Chemical Treatments for Heating and Cooling Systems

5a. CONTRACT NUMBER

5b. GRANT NUMBER

5c. PROGRAM ELEMENT NUMBER

\section{AUTHOR(S)}

Susan A. Drozdz and Vincent F. Hock

5d. PROJECT NUMBER

Reimbursable Order No.

5e. TASK NUMBER

5f. WORK UNIT NUMBER

7. PERFORMING ORGANIZATION NAME(S) AND ADDRESS(ES)

U.S. Army Engineer Research and Development Center (ERDC)

8. PERFORMING ORGANIZATION REPORT NUMBER

Construction Engineering Research Laboratory (CERL)

ERDC/CERL TR-06-29

PO Box 9005,

Champaign, IL 61826-9005

\section{SPONSORING I MONITORING AGENCY NAME(S) AND ADDRESS(ES)}

HQDA, Installation Management Agency

10. SPONSOR/MONITOR'S ACRONYM(S)

2511 Jefferson Davis Highway

Taylor Bldg., Rm 11E08

Arlington, VA 22202-3926

SFIM-OP-P

11. SPONSOR/MONITOR'S REPORT NUMBER(S)

\section{DISTRIBUTION I AVAILABILITY STATEMENT}

Approved for public release; distribution is unlimited.

\section{SUPPLEMENTARY NOTES}

\section{ABSTRACT}

The development of current selection and application guidance is necessary to help Army installations be "smart buyers" of water treatment for new and existing heating and cooling systems. Manufacturers continue to introduce new chemicals and treatment programs onto the market, including environmentally friendly "green” chemical products, as old products are discontinued. These products require periodic review to inform Army installations of new technological advances, and of the capabilities of chemical products available in the marketplace.

This work demonstrated and evaluated the performance of primary water treatment formulations at Fort Stewart, GA and Fort Hood, TX, using three "green" chemical technologies: (1) the cooling water inhibitor polyaspartate (PASP), (2) the cooling water biocide tetrakis (hydroxymethyl) phosphonium sul-fate (THPS), and (3) a filming inhibitor made from exthoxalated soya amines (for steam line treatment). The study concluded that the three technologies were effective when used according to the recommended application guidelines.

\section{SUBJECT TERMS}

Ft. Stewart, GA Ft. Hood, TX HVAC

cooling systems central heating plants

heating systems HVAC

\begin{tabular}{|l|l|l|}
\hline $\begin{array}{c}\text { a. REPORT } \\
\text { Unclassified }\end{array}$ & $\begin{array}{c}\text { b. ABSTRACT } \\
\text { Unclassified }\end{array}$ & $\begin{array}{c}\text { c. THIS PAGE } \\
\text { Unclassified }\end{array}$ \\
\hline
\end{tabular}

17. LIMITATION
OF ABSTRACT
SAR

\begin{tabular}{|c|c|}
$\begin{array}{c}\text { 18. NUMBER } \\
\text { OF PAGES }\end{array}$ & | \\
\cline { 2 - 2 } & \\
&
\end{tabular}

